\title{
Zoogeography, ecology, and conservation status of the large freshwater mussels in Sweden
}

\author{
Ted von Proschwitz $\cdot$ Niklas Wengström
}

Received: 4 October 2019/Revised: 28 June 2020/Accepted: 8 July 2020/Published online: 27 July 2020

(C) The Author(s) 2020

\begin{abstract}
The Swedish fauna of native Unionids contains one Margaritiferidae species, six Unionidae species and four non-native species, one Unionidae, two Dreissenidae and one Mactridae. This is the first attempt to describe the Swedish freshwater mussel species in detail and put them in context with zoogeography, ecology, and conservation status. Detailed distribution maps for all species, based on all available material in museum collections, databases and literature are presented. Details in the distributions, and possible causes for the different geographical patterns exhibited, especially the so
\end{abstract}

Guest editors: Manuel P. M. Lopes-Lima, Nicoletta Riccardi, Maria Urbanska \& Ronaldo G. Sousa / Biology and Conservation of Freshwater Molluscs.

T. von Proschwitz

Gothenburg Museum of Natural History, Box 7283,

40235 Gothenburg, Sweden

T. von Proschwitz

Gothenburg Global Biodiversity Centre, University of

Gothenburg, Box 461, 40530 Gothenburg, Sweden

N. Wengström ( $\bowtie)$

Department of Biological and Environmental Sciences, University of Gothenburg, Box 463, 40530 Gothenburg, Sweden

e-mail: niklas.wengstrom@bioenv.gu.se

N. Wengström

Swedish Anglers Association, Sjölyckan 6, 41655 Gothenburg, Sweden called limes norrlandicus - an important biogeographical transition zone in Central Sweden-are discussed. Information on the ecology, especially host fish species, and conservation status and projects are also given.

Keywords Freshwater bivalves - Unionoid mussels · Sweden · Zoogeography · Ecology · Host fish ·

Conservation

\section{Introduction}

Freshwater bivalves of the order Unionida Gray, 1854 have a worldwide distribution with more than 800 species (Graf \& Cummings, 2007; Bogan, 2008) and they are found on every continent except for Antarctica (Bogan, 2008). The greatest diversity is found in North America with more than 300 species (Bogan, 2008) followed by East and South Asia ( $>200$ species) (Zieritz et al., 2018) and South America (> 150 species) (Graf \& Cummings, 2007). In Europe, the diversity is limited to two families, Unionidae and Margaritiferidae, and 17 species (Lopes-Lima et al., 2016; Froufe et al., 2017). The Swedish biodiversity of freshwater bivalves (orders: Unionida \& Venerida Gray, 1854) consist of seven native species: one in the Margaritiferidae Hendersson, 1929 (1910): freshwater pearl mussel Margaritifera margaritifera (Linnaeus, 
1758); and six in the Unionidae Rafinesque, 1820: painter's mussel Unio pictorum (Linnaeus, 1758), swollen river mussel U. tumidus Philipsson, 1788, thick-shelled river mussel $U$. crassus Phililsson, 1788, duck mussel Anodonta anatina (Linnaeus, 1758), swan mussel A. cygnea (Linnaeus, 1758) and the depressed river mussel Pseudanodonta complanata (Rossmässler, 1835) (Table 1). In addition four nonnative, invasive species have been found: one in the Unionidae: the chinese pond mussel Sinonodonta woodiana (Lea, 1834), two in the Dreissenidae Gray, 1840: zebra mussel Dreissena polymorpha (Pallas 1771) and Conrad's false mussel Mytilopsis leucophaeata (Conrad, 1831); and one in the Mactridae Lamarck, 1809: Atlantic rangia Rangia cuneata (GB Sowerby I, 1832) (Table 1). Mytilopsis leucophaeata and $R$. cuneata have been included in the present study, although they, so far have been found only in brackish water (von Proschwitz, 2018), but as occurrences in England show (Willing, 2015), they might in the future also invade freshwater habitats. In addition to the large freshwater mussels, about 23 (depending on species limitation) species of small freshwater mussels (family Sphaeriidae) have been found in Sweden (Kuiper et al., 1989; von Proschwitz, 1998) they are not considered further here as we have no complete compilation of the material, and some species groups are also in need of modern taxonomical revision.

Unionids are fascinating animals that lives in the bottom substrate in streams and lakes. They are filter feeders and they perform several important ecosystem services, e.g., nutrient cycling, biofiltration and habitat modification (Vaughn, 2018). Mussel filtrations can remove, disease organism (Izumi et al., 2012), viruses (Faust et al., 2009), and pharmaceuticals (Ismail et al., 2015) from the water column.

The unionid life cycle includes an egg-, larva- and mussel stage, and these stages can vary between species, e.g., reproductive period, hermaphroditic or separate sex, short-term breeders and long-term breeders, hooked and hookless larva, and differences in larval development time on the host. They all have a parasitic larva, which metamorphose to a juvenile mussel on a host (Kat, 1984). Almost all mussel species have fish as their primary host, but there are

Table 1 Species of large freshwater mussels occurring in Sweden and number of records (localities) in the time periods $1950<; \geq 1950$ and total

\begin{tabular}{|c|c|c|c|c|}
\hline Species & Red list category & $\begin{array}{l}\text { Number of sites } \\
<1950 \text { only }\end{array}$ & $\begin{array}{l}\text { Number of sites } \\
\geq 1950\end{array}$ & $\overline{\text { Total }}$ \\
\hline Margaritifera margaritifera (Linnaeus, 1758) & $\mathrm{EN}$ & 169 & 965 & 1134 \\
\hline Unio pictorum (Linnaeus, 1758) & NT & 82 & 225 & 307 \\
\hline Unio tumidus Philipsson, 1788 & & 135 & 680 & 815 \\
\hline Unio crassus Philipsson, 1788 & $\mathrm{EN}$ & 38 & 350 & 388 \\
\hline Anodonta anatina (Linnaeus, 1758) & & 283 & 1542 & 1825 \\
\hline Anodonta cygnea (Linnaeus, 1758) & & 84 & 376 & 460 \\
\hline Pseudanodonta complanata (Rossmässler, 1835) & NT & 73 & 249 & 322 \\
\hline Sinanodonta woodiana (Lea, 1834) & & - & 4 & 4 \\
\hline Dreissena polymorpha (Pallas, 1771) & & 12 & 114 & 126 \\
\hline Mytilopsis leucophaeata (Conrad, 1831) & & - & 2 & 2 \\
\hline Rangia cuneata (GB Sowerby I, 1832) & & - & 3 & 3 \\
\hline Total & & 876 & 4510 & 5386 \\
\hline
\end{tabular}

Note that if a species is found in the same site both $<$ and $\geq 1950$ it is only been counted as $\geq 1950$; and that the number says nothing about the status of the populations as such. The red list categories are given according to ArtDatabanken (2020) 
species that use other species than fish as host, e.g., the north-American salamander mussel Simpsonaias ambigua Say, 1825 that infest the common mudpuppy Necturus maculosus Rafinesque, 1818. The unionid larva is called glochidia and they can have hooks (Anodontinae and Unionidae) or be hookless (Margaritiferidae) (Kat, 1984). Hooked glochidia can attach to body, fins, and gills on the host and the hookless glochidia can only attach to the gills.

The reproductive period of the long-term breeders, A. anatina and A. cygnea has not been studied in Sweden, but we assume that it probably does not differ from the timing in other European populations. In Finland, Portugal and U.K. the spawning of A. anatina starts in June-September, and the females carry the glochidia until March-April the following year when they release glochidia (Jokela et al., 1991; Aldridge, 1999; Hinzmann et al., 2013). In Turkey, the reproductive period of A. cygnea starts in July and ends in June the following year when the female release glochidia (Başçınar \& Düzgüneş, 2009). Glochidia from A. anatina and A. cygnea have been found in April-May on infested fish caught in the provinces of Västergötland (Fig. 1, nr: 22), Småland (Fig. 1, nr: 16) and Närke (Fig. 1, nr: 14) (Wengström, 2009; Larsson, 2015; Jonsson \& Bertilsson, 2016). The knowledge about the reproductive period for $P$. complanata is also scarce, but we assume it is similar to what has been reported from the U.K. and Finland, that it has its reproductive period between May and July (Pekkarinen, 1993; Aldridge, 1999). Glochidia from P. complanata have been found on infested fish in June from three Swedish provinces (Fig. 1, nr: 14, 16 \& 22). According to Pekkarinen (1993) the time between the gravidity periods of $P$. complanata in Finland is only an extremely short period in June. The knowledge of the short-term breeders $U$. crassus, $U$. pictorum and $U$. tumidus in Sweden is also incomplete, with the exception for $U$. crassus which starts its reproductive period in April, and it last until July (Lundberg \& Österling, 2016). The reproductive period for Swedish populations of $U$. pictorum and $U$. tumidus is probably the same as in other European populations, which seem to have their reproductive period between April and October (Pekkarinen, 1993; Aldridge, 1999; Blažek \& Gelnar, 2006). The long period, between April and October, found in the Czech Republic (Blažek \& Gelnar, 2006) has not been observed in Sweden. Margaritifera margaritifera has its reproductive period between June and September like in other countries in Europe, e.g., the U.K. (Hastie \& Young, 2003) and southern Germany (Bauer, 1987).

The decline of freshwater biodiversity is an ongoing worldwide problem (Dudgeon et al., 2006) and unionids are particularly threatened (Lydeard et al., 2004). The most common threats discussed in literature are habitat destruction, loss of host fish, pollution, commercial exploitation, and introduced species (Bogan, 1993). A new threat is the enigmatic mussel dieoffs that have been reported from the United States of America (Haag, 2019; Waller \& Cope, 2019) and from Sweden (Wengström et al., 2019). These phenomena have yet no explanation, but science suggests diseases and invasive species as vectors for viruses or parasites, to be factors that may explain the die-offs (Haag, 2019). The global conservation status of the unionids occurring in Sweden are as follows; M. margaritifera Endangered (Moorkens et al., 2017); U. crassus Endangered (Lopes-Lima et al., 2014c); U. pictorum Least concern (Van Damme, 2011); U. tumidus Least concern (Van Damme, 2011); A. anatina Least concern (Lopes-Lima, 2014b); A. cygnea Least concern (Lopes-Lima, 2014a) and P. complanata Vunerable (Van Damme, 2011). The European assessments for the same species is a little different from the global assessments; M. margaritifera Critically endangered (Moorkens, 2011); U. crassus Vunerable (Aldridge et al., 2011); U. pictorum Least concern (Vavrova, 2011); U. tumidus Least concern (Vavrova, 2011); A. anatina Least concern (Killeen \& Vavrova, 2011); A. cygnea Near threaten (Killeen \& Aldridge, 2011) and P. complanata Near threaten (Aldridge, 2011).

\section{Materials and methods}

\section{Zoogeography}

In the 1990s a taxonomic revision of all Swedish material of large freshwater mussels (Margaritiferidae, Unionidae, Dreissenidae) found in the collections of the Natural History Museums of Göteborg, Stockholm, Lund and Uppsala started. This material, which originates from the 18th century and forward until today, forms the base for the compilation of national distribution maps for all species (Figs. 2, 3, 4, 5, 6, 7, 8, 9, and 10) (von Proschwitz, 2006). With the breakthrough of the modern conservation thinking in 


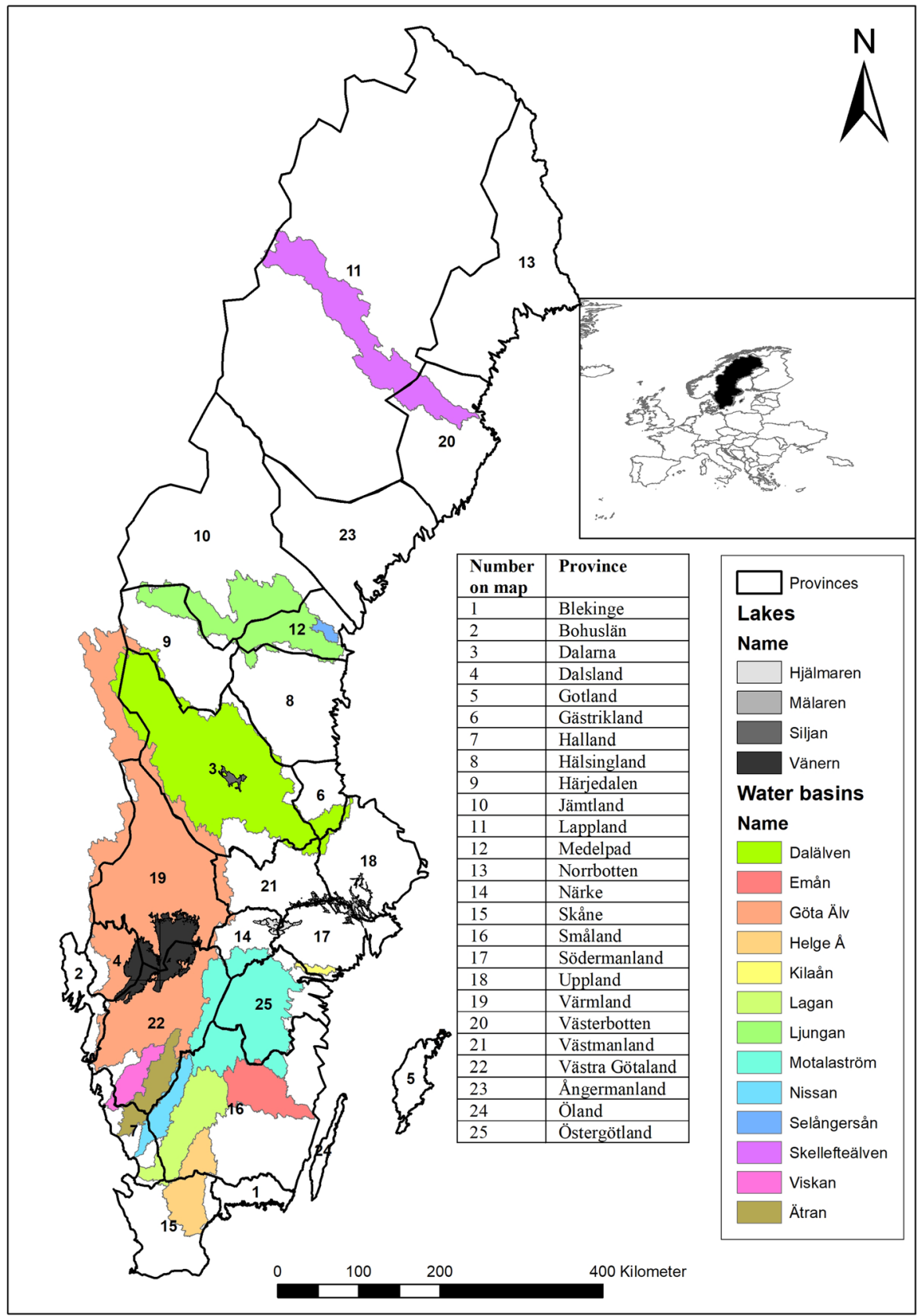

Fig. 1 Swedish provinces, water basins and lakes mentioned in the text. In the map of Europe Sweden is colored black

the late 1980s, first concerning Margaritifera margaritifera (Linnaeus, 1758) (Grundelius, 1987; Ájtte ed., 1995), and later with all species, new material and data from all parts of Sweden has gathered rapidly. Especially after the developed monitoring protocols for large freshwater mussels in Sweden started (cf. Henrikson et al., 2005; Lundberg et al., 2006;
Bergengren et al., 2010). Further data records have been collected from several County Boards from the databases Musselportalen (www.musselportalen.se) and Artportalen (www.artportalen.se) at the Swedish Species Information Centre (ArtDatabanken). The ongoing research and monitoring has also resulted in much new knowledge on the habitat preferences and 


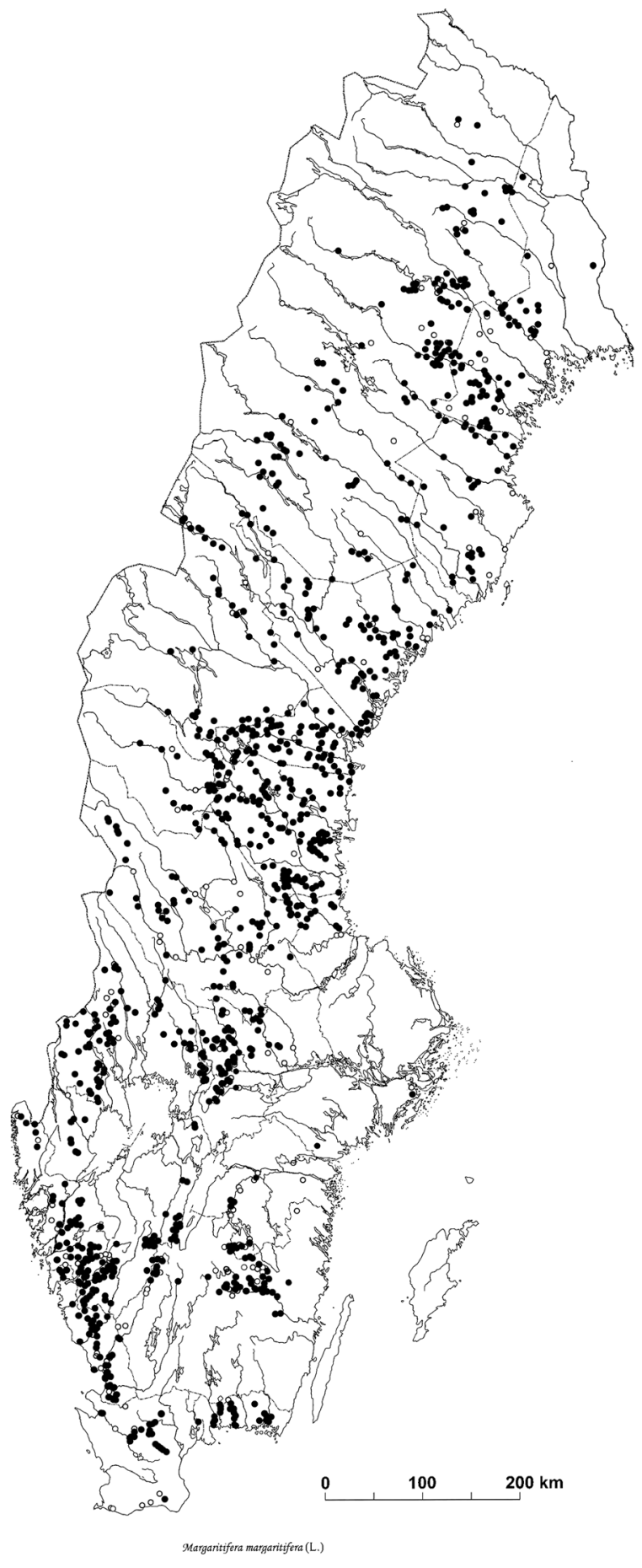

Fig. 2 The distribution of M. margaritifera in Sweden. Open circles-records before 1950 only; black dots records 1950 and later

the reproduction biology of the species-these data were used for Sweden/Scandinavia in the pan-

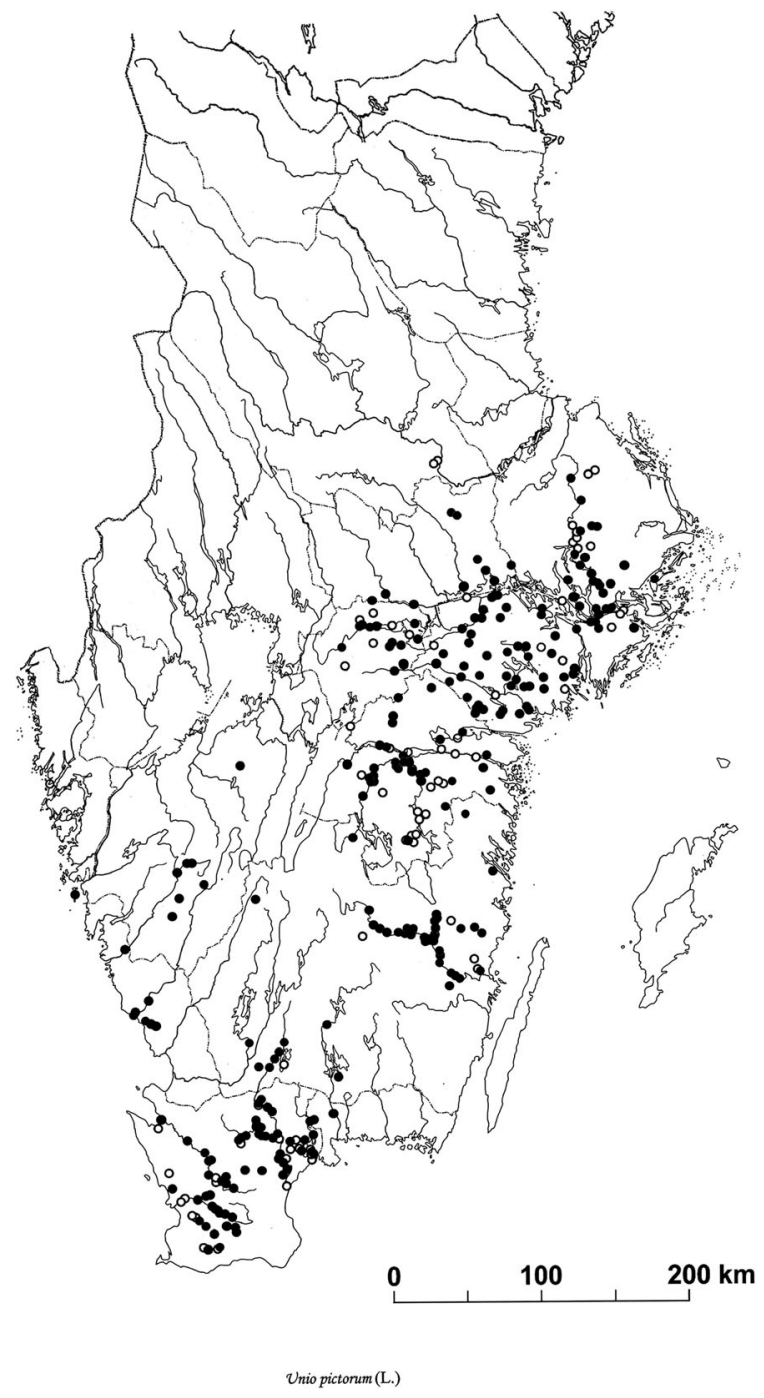

Fig. 3 The distribution of $U$. pictorum in Sweden. Open circles-records before 1950 only; black dots records 1950 and later

European compilation of the knowledge and status of the European unionoids (Lopes-Lima et al., 2016).

Parallel with the revision of museum materials in the 1980s, an ongoing search for and collection of mussel publications (including all kinds of "grey" reports, law regulations etc.) for an annotated national Swedish large freshwater mussel bibliography (von Proschwitz, 2006, 2012). The bibliography covers the time span from 1539 until today, and in 2018 it comprised 2109 titles. All species records, mentioned in this literature, have been evaluated and, if accepted, used in the mapping. The problem of dealing with old 


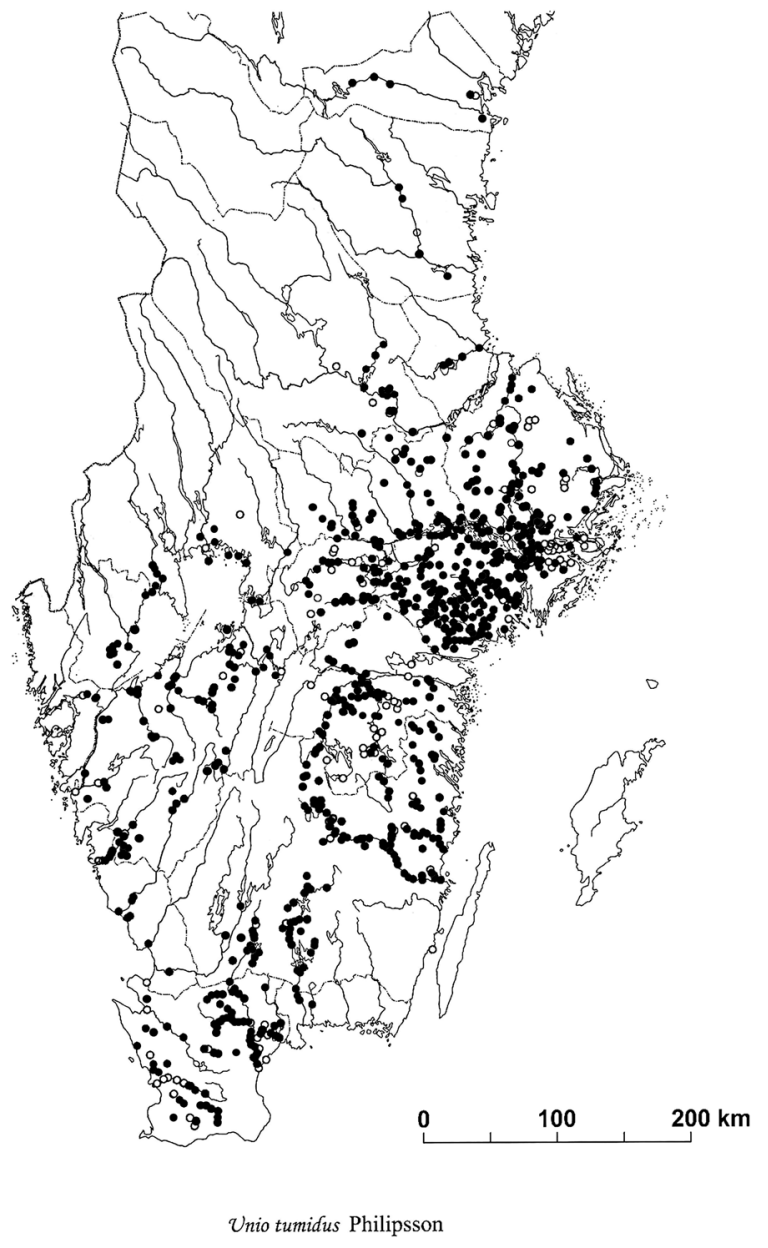

Fig. 4 The distribution of U. tumidus in Sweden

literature records can be exemplified by a more than 340 years old verdict of illegal pearl fishery from 1670 , which was wrongly based on an occurrence of Unio crassus (Philipsson, 1788) (!) instead of $M$. margaritifera (von Proschwitz \& Bergengren, 2012).

A first version of the maps was published as a part of species information sheets in Swedish (von Proschwitz et al., 2006) and a recently updated version (von Proschwitz et al., 2017). Much of these data were used in the pan-European distribution maps published in Lopes-Lima et al. (2016), although the distribution in these are rather rough, as they indicate distribution after water basins. We here present more precise distribution maps with all records marked exactly in the maps. A distinction between "old" $(<1950)$ and "more recent"; $(\geq 1950)$ were made as the mapping started in the 1990s, this rough estimate was set in

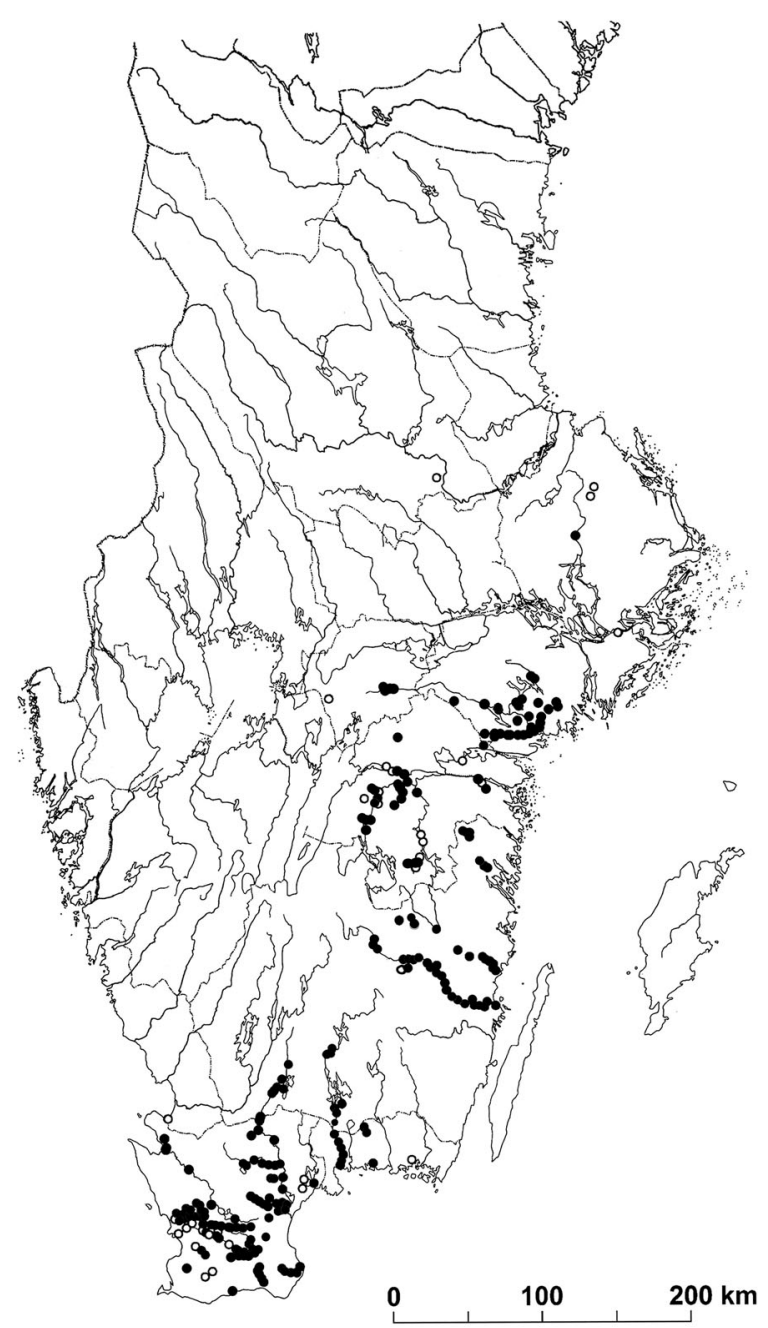

Unio crassus Philipsson

Fig. 5 The distribution of $U$. crassus in Sweden. Open circles-records before 1950 only; black dots records 1950 and later

accordance with the, at that time, recently published distribution maps and zoogeographical analysis of the N. European small freshwater mussels (Sphaeriidae) (Kuiper et al. 1989). These new distribution maps (Figs. 2, 3, 4, 5, 6, 7, 8, 9, and 10) are based on a total of 5386 species records from museum collections, literature, and databases (cf. above and Table 1). They present both current and extinct populations and records only before 1950 are marked with open circles, records from 1950 and later with dots. Provinces and water basins mentioned in the text are illustrated in Fig. 1. 


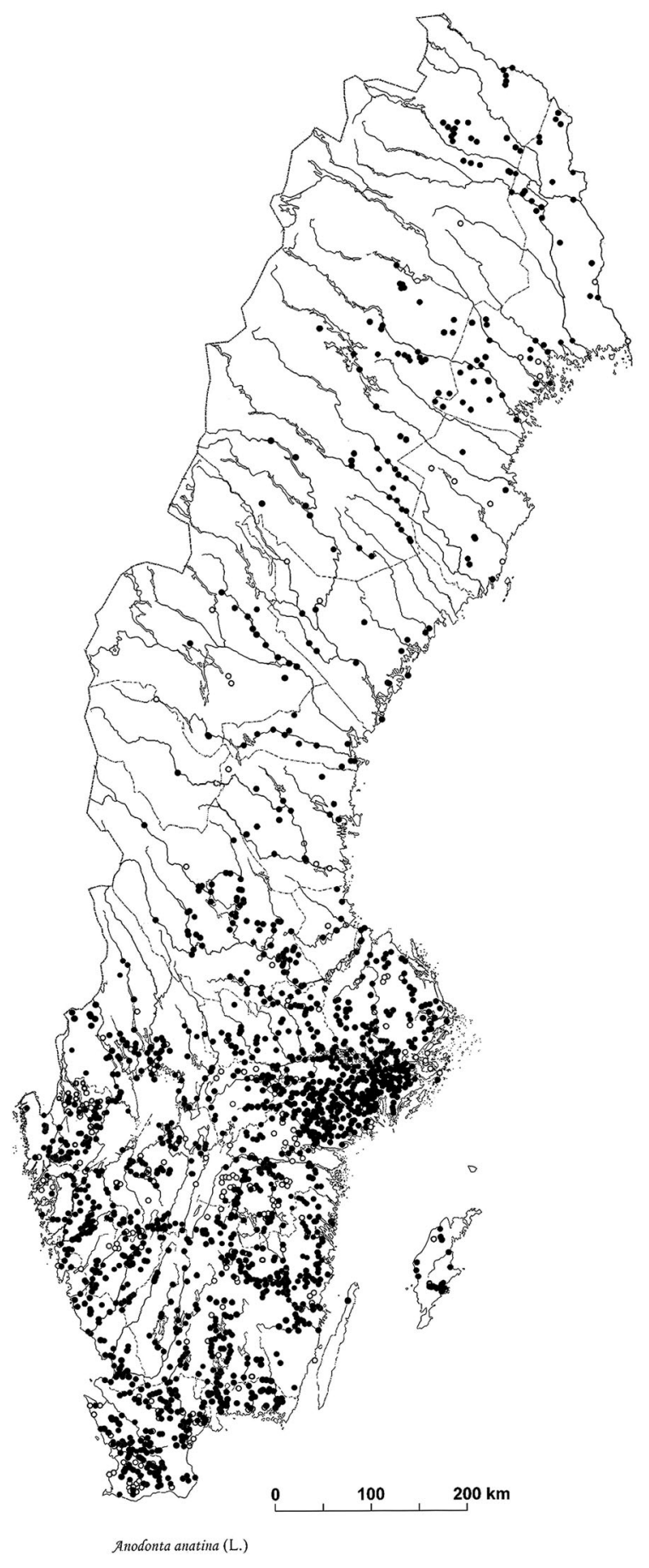

Fig. 6 The distribution of A, anatina in Sweden. Open circles-records before 1950 only; black dots records 1950 and later

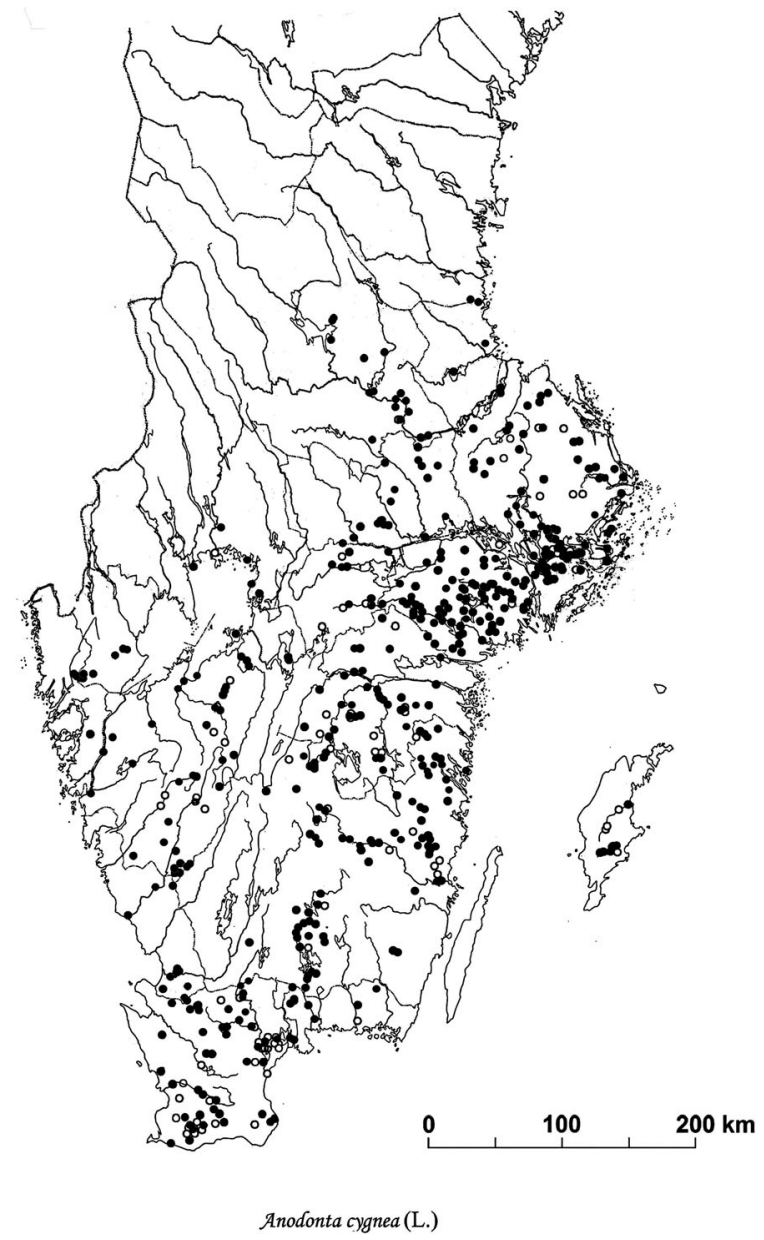

Fig. 7 The distribution of A. cygnea in Sweden

Ecology

The presented host fish mapping is taken from master theses, host fish mapping projects and the former Life project UC4Life (Wengström, 2009; Larsson, 2015; Jonsson \& Bertilsson, 2016; Lundberg \& Österling, 2016; Andersson, 2020) (Table 2). In all these references host fish have been determined from DNAanalysis from infested glochidia and in some cases excysted juveniles using the protocols from Källersjö et al. (2005) and Zieritz et al. (2012). We use the terms possible and functional host fish depending on which method that have been used in the study. A possible host is defined as a fish which contains encysted glochidia and a functional host is defined as a fish that delivers viable juveniles-defined as excysted juveniles with foot movement. 


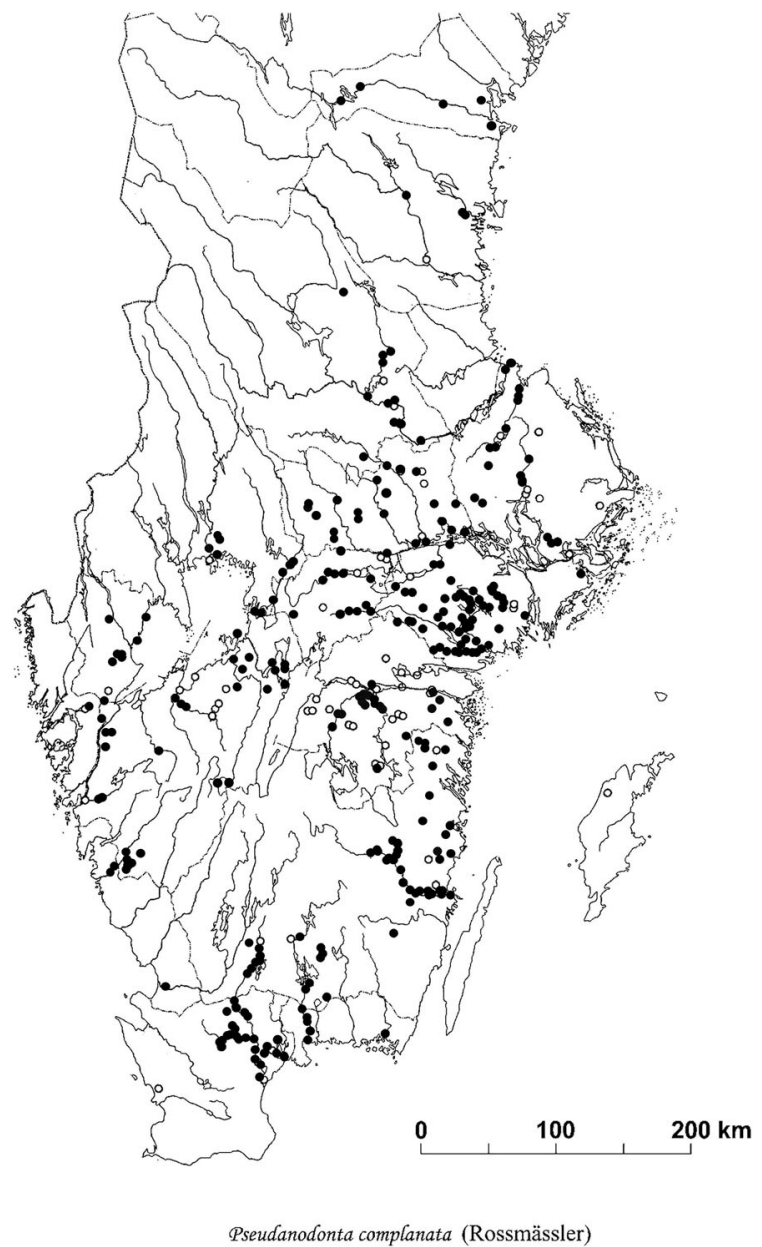

Fig. 8 The distribution of $P$. complanata in Sweden. Open circles-records before 1950 only; black dots records 1950 and later

\section{Results}

Freshwater pearl mussel, Margaritifera margaritifera (Linnaeus, 1758)

\section{Zoogeography}

This species is distributed almost throughout the entire country (Fig. 2), from the province of Skåne (Fig. 1, nr: 15) in the south to northernmost Lapland (Fig. 1, nr: 11). It should be stressed that the map only shows the distribution, and nothing about the population status, the only marking is if the species has been found after, or only before 1950. Margaritifera margaritifera has several natural distribution gaps. It does not occur in high altitudes in the Scandinavian

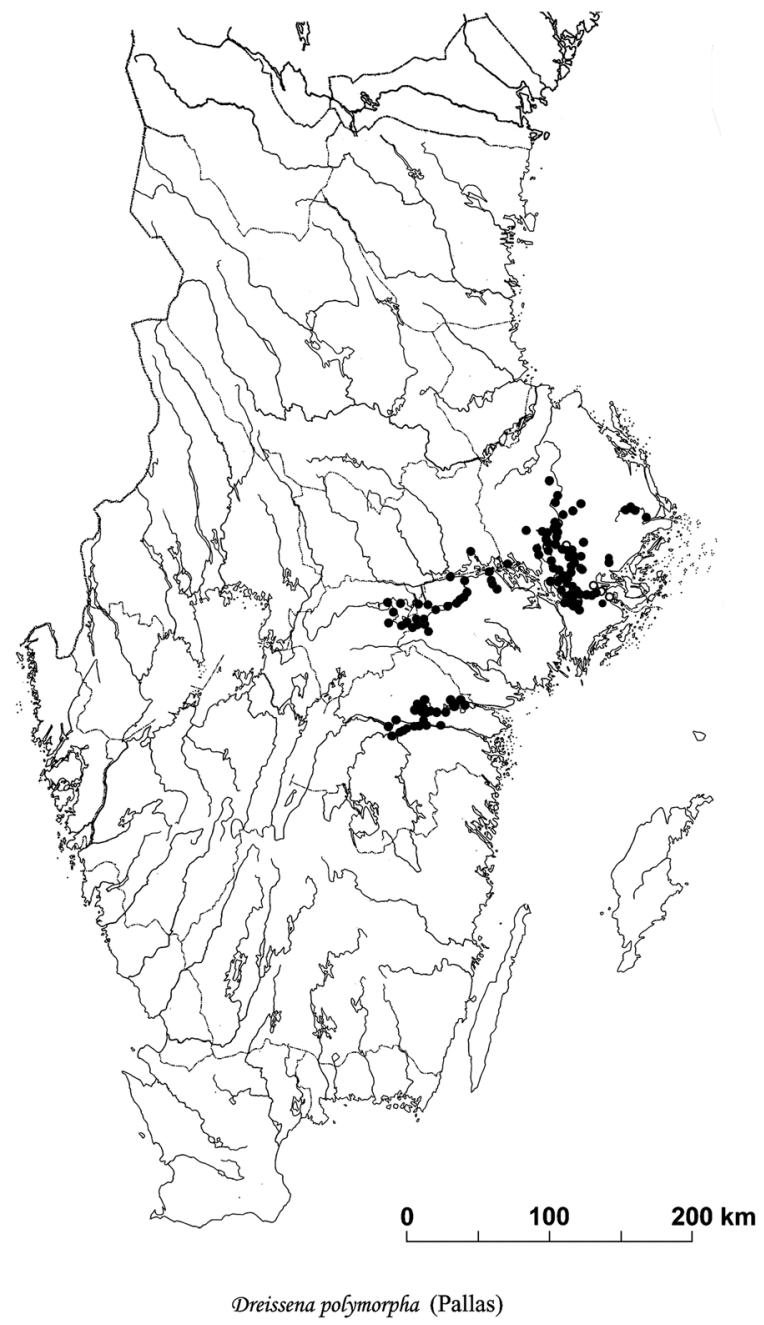

Fig. 9 The distribution of D. polymorpha in Sweden. Open circles-records before 1950 only; black dots records 1950 and later

mountain range - this distribution limit in the west is strongly marked. There is also a large gap in the eastern part of Central Sweden (the provinces around Lake Mälaren, Fig. 1, nr: 17 \& 18), which is an area where silt and clay sediment dominate, and the watercourses hence unsuitable for the species. There does not seem to be any correlation of the distribution of M. margaritifera and bedrock. The species occurs in both crystalline and lime rich areas and the distribution gaps (Fig. 2) do not directly correspond to differences in geology. Some distribution gaps, especially in the south ( $S$ part of the province of Småland, Fig. 1, nr: 16) may also be due to eradication (drainage, effects of forestry, pearl fishery, dams, 


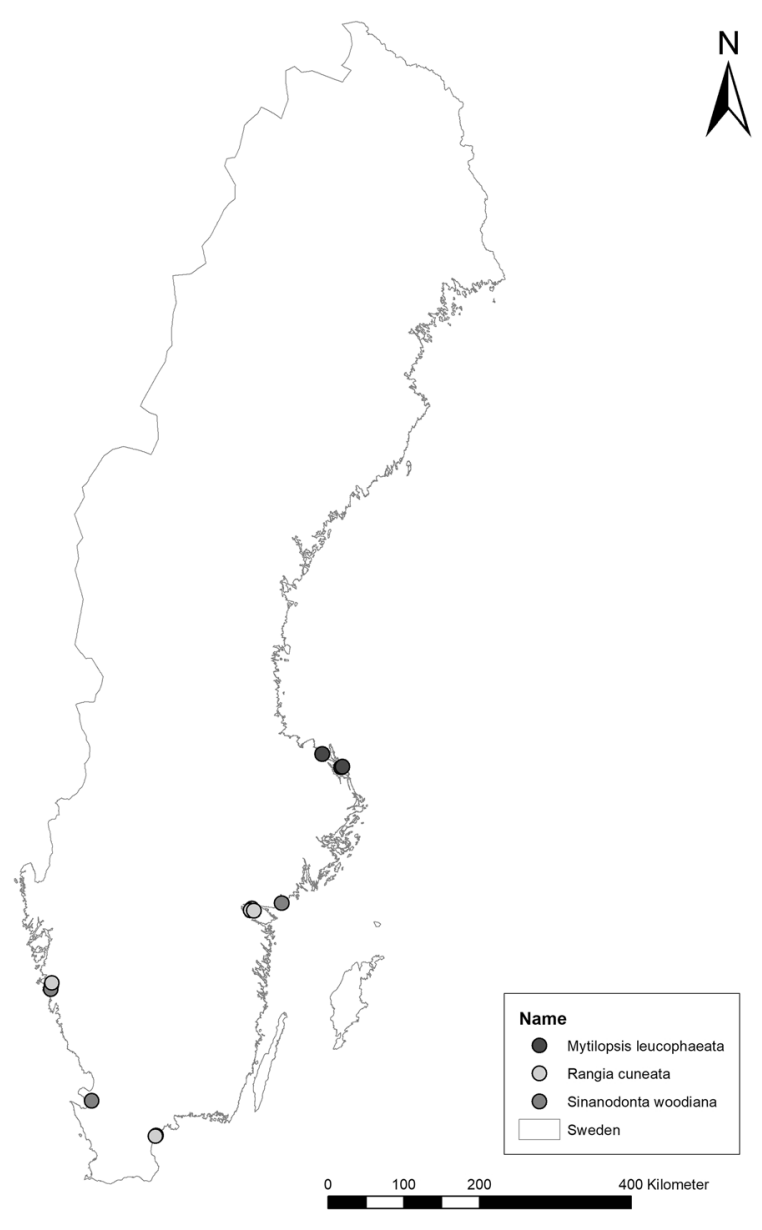

Fig. 10 The distribution of S. woodiana, M. leucophaeata and $R$. cuneata in Sweden

logging_cf. von Proschwitz, 2012) due to human activities in historical time.

\section{Ecology}

The species occur in streams on almost every substrate, from fine sediment to course gravel, but the most common substrate where it is found is a mix between sand and gravel.

The reproductive period is between June and September, which is like in the rest of Europe (Bauer, 1987; Hastie \& Young, 2003). In Sweden gravid females can be found between July to September. There is a gradient from the south to the north with the earliest releases of glochidia in the south. Infested fish carry the glochidia until the middle of June in the south part of Sweden (Wengström, unpublished data), we do not know exactly when the juveniles excyst from the fish in the northern parts of Sweden.

Margaritifera margaritifera is a host fish specialist, restricted to Atlantic salmon Salmo salar (Linnaeus, 1758) Salmonidae and brown trout $S$. trutta (Linnaeus, 1758) Salmonidae. The most common host fish to $M$. margaritifera in Sweden is S. trutta. (Österling et al., 2008; Österling \& Wengström, 2015).

\section{Conservation}

Intense pearl fishery was during many centuries, from Medieval until the nineteenth century, a main threat to M. margaritifera in Sweden (Awebro, 1995; von Proschwitz, 2012). From the 1980s and onwards there has been a rapidly rising interest in the species' ecology and conservation. An important summary of the species national status and threats was published in 1998 (Eriksson et al., 1998) and the first species action plan in 2005 (Schreiber et al., 2005) which has been revised in 2018 (Henrikson \& Söderberg, 2020). A LIFE project: The freshwater pearl mussel and its habitats in Sweden, was running 2004-2009 (WWF, 2009; Henrikson \& Alexanderson, 2012). Several other LIFE projects after that have included $M$. margaritifera in different work packages, e.g., within GRIP ON LIFE a propagation facility will be established.

Exploitation of rivers for hydroelectricity (including dam construction and following fragmenting of the watercourses), and in some cases pollution, has reduced the total population considerably, especially in Southern Sweden, during the last three generations (= 100 years). This equals a reduction of approx. 50\% for the whole country. The species has disappeared from approx. $1 / 3$ of the watercourses in which it occurred in the beginning of the 20th century. The phenomena of enigmatic mussel die-offs have also been reported from Sweden in 17 different populations and with a mortality of $100 \%$ in some of the populations (Wengström et al., 2019). Reproduction is successful in only $1 / 3$ of the water courses in which the species still lives; there are however considerable regional differences - in large area in Northern, and some areas in Western Sweden, there are still viable populations (Söderberg et al., 2008). The total number of watercourses with populations is estimated to 628 (550-700), of which 258 has confirmed reproduction. The extent of occupancy (EOO) exceeds the limit for 
Table 2 Possible (P) and functional (F) fish hosts in Sweden

\begin{tabular}{|c|c|c|c|c|c|c|c|c|c|}
\hline Common name & Species & Family & $\mathrm{Mm}$ & $\mathrm{Uc}$ & $\mathrm{Up}$ & $\mathrm{Ut}$ & $\mathrm{Aa}$ & Ac & $\mathrm{Pc}$ \\
\hline Bleak & Alburnus alburnus (Linnaeus, 1758) & Cyprinidae & & $\mathrm{F}$ & & $\mathrm{F}$ & & $\mathrm{P}$ & \\
\hline Blicca bjoerkna & Blicca bjoerkna (Linnaeus, 1758) & Cyprinidae & & $\mathrm{P}$ & & & & & \\
\hline Common dace & Leuciscus leuciscus (Linnaeus, 1758) & Cyprinidae & & & & $\mathrm{P}$ & $\mathrm{P}$ & $\mathrm{P}$ & \\
\hline Common minnow & Phoxinus phoxinus (Linnaeus, 1758) & Cyprinidae & & $\mathrm{F}$ & & $\mathrm{P}$ & $\mathrm{F}$ & & \\
\hline Common roach & Rutilus rutilus (Linnaeus, 1758) & Cyprinidae & & $\mathrm{F}$ & $\mathrm{P}$ & & & $\mathrm{P}$ & \\
\hline Chub & Squalis cephalus (Linnaeus, 1758) & Cyprinidae & & $\mathrm{P}$ & & & & & \\
\hline Tench & Tinca tinca (Linnaeus, 1758) & Cyprinidae & & $\mathrm{P}$ & & & & & \\
\hline Vimba bream & Vimba vimba (Linnaeus, 1758) & Cyprinidae & & $\mathrm{P}$ & & & & & \\
\hline Stone loach & Barbatula barbatula (Linnaeus, 1758) & Balitoridae & & $\mathrm{P}$ & & & & & \\
\hline Brown trout & Salmo trutta (Linnaeus, 1758) & Salmonidae & $\mathrm{F}$ & $\mathrm{P}$ & & $\mathrm{F}$ & $\mathrm{P}$ & & $\mathrm{P}$ \\
\hline Atlantic salmon & Salmo salar (Linnaeus, 1758) & Salmonidae & $\mathrm{F}$ & & & & $\mathrm{P}$ & $\mathrm{P}$ & $\mathrm{P}$ \\
\hline Northern pike & Esox lucius (Linnaeus, 1758) & Esocidae & & & & $\mathrm{P}$ & & & \\
\hline Burbot & Lota lota (Linnaeus, 1758) & Lotidae & & $\mathrm{F}$ & $\mathrm{P}$ & $\mathrm{F}$ & & & \\
\hline Three- spined stickleback & Gasterosteus aculeatus (Linnaeus, 1758) & Gasterosteidae & & & & & $\mathrm{P}$ & & \\
\hline European bullhead & Cottus gobio (Linnaeus, 1758) & Cottidae & & $\mathrm{F}$ & & $\mathrm{F}$ & $\mathrm{F}$ & & $\mathrm{P}$ \\
\hline Ruffe & Gymnocephalus cernuus (Linnaeus, 1758) & Percidae & & $\mathrm{P}$ & $\mathrm{P}$ & & $\mathrm{F}$ & $\mathrm{P}$ & \\
\hline European perch & Perca fluviatilis (Linnaeus, 1758) & Percidae & & $\mathrm{F}$ & $\mathrm{P}$ & $\mathrm{F}$ & & $\mathrm{P}$ & \\
\hline
\end{tabular}

Mm Margaritifera margaritifera, Uc Unio crassus, Up Unio pictorum, Ut Unio tumidus, Aa Anodonta anatina, Ac Anodonta cygnea, Pc Pseudanodonta complanata

red listing. The area of occupancy (AOO) is estimated to $3840 \mathrm{~km}^{2}$. A reduction of the total population is ongoing and/or expected. The reduction affects the quality of habitats and the number of reproductive individuals. The rate has been $49-65 \%$ during the last 100 years. The assessment is based on an appropriate abundancy index, reduction of the AOO and deteriorated habitat quality. Depending on which of the approximated values which are used, the assessment varies from vulnerable (VU) to endangered (EN). Based on the most reliable values the species is placed in category EN. The reduction exceeds the limit for EN according to the A-criterion (A2bce) (ArtDatabanken 2015a, b, 2020; von Proschwitz et al., 2017). The species is protected by law in the whole country since 1994. Margaritifera margaritifera is monitored every year in both national and regional survey programs (e.g., Olofsson, 2017, Wengström et al., 2020).
Painter's mussel, Unio pictorum (Linnaeus, 1758)

\section{Zoogeography}

The species is markedly rarer in the west than in the east (Fig. 3). In the west the occurrences are scattered and limited to a few river systems. The eastern distribution can be divided into three-subareas: (I) The province of Skåne (Fig. 1, nr: 15) and the adjacent areas of the provinces of Blekinge and Småland (Fig. 1, nr: $1 \& 16$ ). (II) The water system of river Emån in E. Småland (Fig. 1, nr: 16), and (III) a larger area comprising the provinces of Östergötland (Fig. 1, nr: 25), Södermanland (Fig. 1, nr: 17) and Närke (Fig. 1, nr: 14) and the southern part of the provinces of Västmanland (Fig. 1, nr: 21) and Uppland (Fig. 1, nr: 18), north of Lake Mälaren. The northernmost recent records are from the systems of the stream Fyrisån (Uppland) and Svartån (Västmanland). The species seems to have died out in its former (19th century) northernmost Swedish sites in the system of river Dalälven (Fig. 1, nr: 3, 6, 18 \& 21). 
Ecology

The species is considered competition weak, and its populations are often small. It can be found in both lakes and streams but avoids rapid sections of water courses. Unio pictorum prefers soft bottoms with fine sediments as clay and silt, but it also occurs on more hard bottoms with sand and gravel. It is mostly found in medium to marked, natural eutrophic waters. It usually occurs rather shallow, down to 5-6 m (Bergengren et al., 2002a, b; Lundberg \& von Proschwitz, 2007; von Proschwitz et al., 2017).

Their reproductive period in Sweden is like what has been observed in the U.K. (Aldridge, 1999). Infested fish has been found from May to July in the south-eastern part of Sweden. There are no reports from the south-western part.

Functional host fish are unknown, but possible hosts are European perch Perca fluviatilis (Linnaeus, 1758) Percidae, ruffe Gymnocephalus. cernuus (Linnaeus, 1758) Percidae, common roach Rutilus rutilus (Linnaeus, 1758) Cyprinidae and burbot Lota lota (Linnaeus, 1758) Lotidae (Wengström, 2009; Larsson, 2015).

\section{Conservation}

The total number of watercourses with existing populations is estimated to 250 (100-500). The extent of occupancy (EOO) exceeds the limit for red listing. The area of occupancy (AOO) is estimated to 1000 (400-2000) $\mathrm{km}^{2}$. There are indications of that a reduction of the total population is ongoing and/or expected. The reduction affects the quality of habitats and the number of reproductive individuals Depending on which of the approximated values which are used, the assessment varies from near threatened (NT) to last concern (LC). Based on the most reliable values the species belongs in category NT. The reduction falls below the limit for EN, but the fact that the EOO probably is considerably fragmented, and that a reduction presumably is ongoing fulfills the B-criteria for NT (B2ab(iii,v)) (ArtDatabanken 2015a, b, 2020; von Proschwitz et al., 2017). The species is considered as competition weak, but there is considerable lack of knowledge of details in the species reproduction. There are signs of recruitment in only about 15 populations, but the knowledge about reproductive success is very insufficient. Clearing this should have priority in the coming years. The species has been proposed for use in national and regional monitoring (Bergengren \& Lundberg, 2009). A national program started in 2010 with five different water courses being surveyed every sixth year.

Swollen river mussel, Unio tumidus Philipsson, 1788

\section{Zoogeography}

The species is fairly common, occurring in almost all of the whole southern and western Sweden (Fig. 4). In the West, it does not reach north of the southernmost part of the province of Värmland (Fig. 1, nr: 19). In eastern Sweden, however, U. tumidus extends far more to the north, in a broad zone, with scattered occurrences north to the rivers Ljungan and Selångersån in the province of Medelpad (Fig. 1, nr: 12).

\section{Ecology}

The species has similar habitat preferences as $U$. pictorum, as it occurs on both hard and soft bottoms. However, its ecological niche is broader, as it occurs also in more mesotrophic-slightly oligotrophic waters. It can also be found deeper, down to 9-10 m (Bergengren et al., 2002a; b; Lundberg \& von Proschwitz, 2007; von Proschwitz et al., 2017).

Host fish are not completely known, but possible hosts are $P$. fluviatilis, S. salar, S. trutta, common dace Leuciscus leuciscus (Linnaeus, 1758) Cyprinidae, common minnow Phoxinus phoxinus (Linnaeus, 1758) Cyprinidae (Jonsson \& Bertilsson, 2016) and G. cernua, $R$. rutilus, L. lota and northern pike Esox lucius (Linnaeus, 1758) Esocidae, Eropean bullhead Cottus gobio (Linnaeus, 1758) Cottidae (Wengström, 2009; Larsson, 2015). Confirmed functional hosts are L. lota, P. fluviatilis, S. trutta, C. gobio and bleak Alburnus alburnus (Linnaeus, 1758) Cyprinidae (Larsson, 2015).

\section{Conservation}

Being the second most common unionoid mussel species in Sweden there is no obvious need for conservation measures, and the species is classified as LC on national level (ArtDatabanken 2015a, b, 2020, von Proschwitz et al., 2017). The species has been 
proposed for use in national and regional monitoring (Bergengren \& Lundberg, 2009).

Thickshelled river mussel, Unio crassus

Philipsson, 1788

\section{Zoogeography}

The distribution in Sweden is restricted to the southeastern-eastern area with no occurrences at all in western draining rivers north of the province of Skåne $\left(56^{\circ} 42^{\prime} \mathrm{N}\right)$ (Fig. 1, nr: 15 and Fig. 5). The distribution is naturally fragmented into 5-6 subareas, with gaps in interjacent oligotrophic districts. In the north it reached the northern part of the province of Uppland (Fig. 1, nr: 18) and the south-easternmost corner of the province of Dalarna (Fig. 1, nr: 3) (river system of Dalälven)-in these localities, where the species was found at the end of the 19th century, U. crassus is now extirpated. The northernmost locality was situated at $60^{\circ} 30^{\prime} \mathrm{N}$. The eastern distribution is in accordance with the general European distribution, which is broadly continental, and in Russia $U$. crassus reaches farther to the north (cf. Lopes-Lima et al., 2016: Fig. 5a).

\section{Ecology}

Unio crassus is found in water courses, in Sweden mostly of middle or smaller size (brooks, smaller and middle-sized rivers), and sometimes also in running water in the in- and outlet of lakes and tarns. It is found on soft bottoms, with fine sediments silt, sand and gravel. The majority of the habitats are shaded and meso-eutrophic. (Björk, 1962; Bergengren et al., 2002a, b; Lundberg \& von Proschwitz 2004; Lundberg et al., 2006; Lindström, 2007; Lundberg, 2012; Schneider 2017; von Proschwitz et al., 2017).

The reproductive period starts in April and it last until July (Lundberg \& Österling, 2016). The possible fish hosts for $U$. crassus includes seven fish species, Vimba bream Vimba vimba (Linnaeus, 1758) Cyprinidae, stone loach Barbatula barbatula (Linnaeus, 1758) Balitoridae, G. cernua, chub Squalis cephalus (Linnaeus, 1758) Cyprinidae, S. trutta, tench Tinca tinca (Linnaeus, 1758) Cyprinidae, Blicca bjoerkna Blicca bjoerkna (Linnaeus, 1758) Cyprinidae (Wengström, 2009; Larsson, 2015; Lundberg \& Österling, 2016; Schneider, 2017; Wengström unpublished data).
Confirmed functional hosts are A. alburnus, C. gobio, $L$, lota, $R$. rutilus, $P$. phoxinus and $P$. fluviatilis (Larsson, 2015; Lundberg \& Österling, 2016; Schneider, 2017).

\section{Conservation}

An action conservation plan for $U$. crassus was established in 2006 (Lundberg et al., 2006). During the years 2012-2016 the Life project UC4LIFE was running in Sweden (Lundberg \& Österling, 2016). The project involved measurements in 12 streams/rivers in five counties in Southern and Eastern Sweden, including restoration of $200 \mathrm{~km}$ rivers/streams, cultivation and reintroduction of mussels, and research on the species' reproduction (Lundberg \& Österling, 2016; Schneider, 2017). In UC4LIFE a lot of work was performed to identify host fish for successful conservation measures such as local adaptation and temperature and host-dependent reproduction (Schneider et al., 2017; Schneider et al., 2018).

The species is known from approximately 75 watercourses, but functioning reproduction occurs in only about 20 of these. Threats are deterioration of the water quality (acidification, eutrophication, pollution) and destruction of sand and gravel bottoms (including incorrect environmental laws, which oblige dredging and cleaning). The total number of watercourses with existing populations is estimated to $75(65-80)$. The extent of occupancy (EOO) exceeds the limit for red listing. The area of occupancy (AOO) is estimated to $280(260-320) \mathrm{km}^{2}$. A reduction of the total population is ongoing and/or expected. The reduction affects the quality of habitats and the number of reproductive individuals. The rate has been 50 (30-60) \% during the last 100 years. The assessment is based directly on observation, and on an appropriate abundancy index. Depending on which of the approximated values which are used, the assessment varies from vulnerable (VU) to endangered (EN). Based on the most reliable values the species is placed in category EN. The reduction exceeds the limit for EN according to the A-criterion (A2ab) (ArtDatabanken 2015a, b, 2020; von Proschwitz et al., 2017). The species is protected by law in the whole country since 2001 . The species has been proposed for use in national and regional monitoring (Bergengren \& Lundberg, 2009). The program started in 2010 with 16 different water courses being surveyed every sixth year. 
Duck mussel, Anodonta anatina (Linnaeus, 1758)

\section{Zoogeography}

The species is the most common of the Swedish unionoid mussels, occurring throughout the country (Fig. 6) from the province of Skåne (Fig. 1, nr: 15) in the south to northernmost Lapland (Fig. 1, nr: 11). In the south it occurs in almost every watercourse and lake. No difference in number of sites can be seen between the eastern and the western parts, and the distribution appears even. In the north, the occurrences are far more scattered, but this is most certainly due to less extent of sampling in this vast area. Only in the mountain ridge in the west $A$. anatina is completely lacking.

\section{Ecology}

Anodonta anatina is the most eurytopic of all unionoid mussel species occurring in Sweden and can be found in all types and sizes of watercourses, as well as lakes, tarns and ponds-except for the most pronounced oligotrophic. It has also been recorded in brackish water in the Baltic Sea. It occurs on all kinds off bottoms and may descend below $10 \mathrm{~m}$ (Bergengren et al., 2002a, b; Lundberg \& von Proschwitz, 2007; von Proschwitz et al., 2017).

Host fish species are poorly known, but several species are probably used. Glochdia have been found on the possible hosts $S$. salar, S. trutta, L. leuciscus, $P$. phoxinus, A. alburnus, $R$. rutilus, three-spined stickleback Gasterosteus aculeatus (Linnaeus, 1758) Gasterosteidae and C. gobio (Jonsson \& Bertilsson, 2016) and confirmed hosts are P. phoxinus, G. gobio and G. cernuus (Andersson, 2020).

\section{Conservation}

Being the most common and eurytopic unionoid mussel species in Sweden there is no obvious need for conservation measures, and the species is classified as LC on national level (ArtDatabanken 2015a, b, 2020; von Proschwitz et al., 2017). The species has, however, been proposed for use in national and regional monitoring (Bergengren \& Lundberg, 2009).
Swan mussel, Anodonta cygnea (Linnaeus, 1758)

\section{Zoogeography}

The species occurs in the whole of southern Sweden, but unevenly, with large distribution gaps-especially in oligotrophic districts - and it is never as common and frequent as A. anatina. It is somewhat rarer in the west (Fig. 7). In the west the northernmost localities of A. cygnea lies in the southernmost part of the province of Värmland (Fig. 1, nr: 19). In the east it reaches the area of Lake Siljan in the system of river Dalälven in the province of Dalarna (Fig. $1 \mathrm{nr}: 3$ ), and in the coastal area in the south-easternmost corner of the province of Hälsingland (Fig. 1, nr 8).

\section{Ecology}

The species is mainly found in lakes, but also in ponds and canals, sometimes also in slow flowing parts of water courses. Anatina cygnea occurs in naturally eutrophic waters. It prefers soft bottoms with clay, silt and sand. It may descend deep, down to $20 \mathrm{~m}$ (Bergengren et al., 2002a, b; Lundberg \& von Proschwitz, 2007; von Proschwitz et al., 2017).

Host fish are poorly known, but $P$. fluviatilis from Virån have been found with A. cygnea glochidia (Wengström, 2009). Glochidia have also been found on the possible hosts: S. salar, L. leuciscus, G. cernuus, A. alburnus and $R$. rutilus (Jonsson \& Bertilsson, 2016).

\section{Conservation}

Being the third most common unionoid mussel species in Sweden, and although geographically and ecologically somewhat restricted, there is no obvious need for conservation measures, and the species is classified as LC on national level (ArtDatabanken, 2015a, b, 2020; von Proschwitz et al., 2017). The species has, however, been proposed for use in national and regional monitoring (Bergengren \& Lundberg, 2009). 
Depressed river mussel, Pseudanodonta

complanata (Rossmässler, 1835)

\section{Zoogeography}

The total distribution is similar to that of $U$. tumidus, but there are several large distribution gaps in the south (Fig. 8) - e.g., the whole south and western part of the province of Skåne (Fig. 1, nr: 15) and a vast area comprising the central part of the province of Småland (Fig. 1, nr: 16) and the southern part of the province of Västergötland (Fig. 1, nr: 22). In areas where it occurs, the localities are scattered and often isolated. In the west the species occurs northwards to the southernmost part of the province of Värmland (Fig. 1, nr: 19). In eastern Sweden P. complanata, like U. tumidus, extends farther to the north, in a broad zone, with scattered occurrences north to the rivers Ljungan and Selångersån in the province of Medelpad (Fig. 1, nr: 12). It should be noted, that although still no records of specimens exist, eDNA evidence shows that $P$. complanata occurs far more to the north, in the river Skellefteälven (approx. 65 N) (Näslund et al., 2019).

\section{Ecology}

The species occurs in slow flowing parts of larger water courses, but also in lakes. Its occurrences are often geographically restricted, with few and scattered individuals. $P$. complanata prefers naturally eutrophic waters with soft bottoms dominated by silt and sand (Bergengren et al., 2002a, b; Lundberg \& von Proschwitz, 2007; von Proschwitz et al., 2017).

Host fish are poorly known, but C. gobio from Svennevadsån in the provinces of Närke (Fig. 1, nr : 14) has been found with $P$. complanata glochidia and S. salar and S. trutta from Göta älv in the province of Västergötland (Fig. 1, nr: 22) (Larsson, 2015; Jonsson \& Bertilsson, 2016).

\section{Conservation}

The total number of water courses with existing populations is estimated to 300 (100-500). The extent of occupancy (EOO) exceeds the limit for red listing. The area of occupancy (AOO) is estimated to 1200 (400-2000) $\mathrm{km}^{2}$. There are indications of that a reduction of the total population is ongoing and/or expected. The reduction affects the quality of habitats and the number of reproductive individuals. Depending on which of the approximated values which are used, the assessment varies from near threatened (NT) to last concern (LC). Based on the most reliable values the species belongs in category NT. The reduction falls below the limit for EN, but the fact that the EOO probably is considerably fragmented, and that a reduction presumably is ongoing fulfills the B-criteria for NT (B2ab(iii,v)) (ArtDatabanken 2015a, b, 2020; von Proschwitz et al., 2017). The species is considered as competition weak, but there is considerable lack of knowledge concerning the it's reproduction. There is a need for future research to better understand the ecology of this species. The species been proposed for use in in national and regional monitoring (Bergengren \& Lundberg, 2009). This national program started in 2010 and it runs in five different water courses but so far only one survey in each has been performed.

\section{Introduced species}

Sinanodonta woodiana (Lea, 1834), was first observed in Sweden 2005. So far only four records of single specimens or empty shells of this invasive species have been found. The sites are scattered over southern Sweden (provinces of Skåne, Västergötland and Södermanland) (Fig. 10). No reproduction has been observed and the species was most certainly introduced with infested cypirinid fishes, and in one case it was Carassius auratus (Linnaeus, 1758) (cf. von Proschwitz, 2008).

Dreissena polymorpha (Pallas, 1771) is the only invasive non unionoid, which so far has become widespread in Sweden. It was first found in Lake Mälaren in the middle of the 1920s and has long been restricted to the water systems of Lake Mälaren and Hjälmaren (Fig. 1). In 2012 a rapid, continuing expansion of $D$. polymorpha in eastern part of the Motala Ström-Göta Kanal system started (Bergengren et al., 2015). This trend is still going on as new water systems in this part of Sweden have been invaded in the latest years (von Proschwitz, unpublished information) (Fig. 9).

Mytilopsis leucophaeata (Conrad, 1831), was first recorded in the Swedish part of the Baltic Sea in 2011 - in the cool-water outlet of the nuclear power plant at Forsmark 2011 (Florin et al., 2013) (Fig. 10). In 2016 a further record was made some $47 \mathrm{~km} \mathrm{WNW}$ 
of Forsmark (both sites on the northern coast of the province of Uppland) (von Proschwitz, 2018). Experiences from other parts of the Baltic Sea indicate that a rapid expansion is to be expected (von Proschwitz, 2018), possibly also into freshwater (cf. Willing, 2015).

Rangia cuneata (G. B. Sowerby I, 1832) first occurred in the brackish water of the Bay Bråviken (province of Österötland, Baltic Sea) (Fig. 10). It has also been found in a canal in the harbor in Göteborg, W. Sweden (von Proschwitz, 2018) and in 2018 in at Åhus at the east coasts of the province of Skåne (so far, all records in brackish water). Experiences from other parts of the Baltic Sea indicate that a rapid expansion is to be expected (von Proschwitz, 2018), possibly also into freshwater (cf. Willing, 2015).

\section{Discussion}

Zoogeography

Four species: Unio pictorum, U. tumidus, A. cygnea and $P$. complanata have their northern limit in the so called "limes norrlandicus" (Fig. 11). Unio tumidus and $P$. complanata reach farthest to the north of the unionidae (both approx. $62^{\circ} 30^{\prime} \mathrm{N}$ ); A. cygnea approx. $61^{\circ} \mathrm{N}$; and $U$. pictorum approx. $60^{\circ} 30^{\prime} \mathrm{N}$. The limes is an important biogeographical transition zone, which runs through middle Sweden, north of Lake Vänern in the West, eastwards with a marked prolongation northwards to approx. $62^{\circ} \mathrm{N}$ along the Baltic Sea coast. It is often referred to as the northern limit of the oak (Quercus robur Linnaeus, 1753). Within this zone the northern limits of many deciduous trees and other vascular plants as well as of several animals cluster, and it is also the southern limit of many organisms e.g., the dwarf birch (Betula nana Linnaeus, 1753). Its causes are mainly climatological, but there is also a shift in geomorphology of the landscape from the large-scale northern landscape with wide river valleys, to a smaller scaled southern (Fries, 1948; Hård af Segerstad, 1935).

All four species have a continental distribution, being far more common in eastern Sweden than in western Sweden. Characteristically, they also reach more to the north in Finland (Lopes-Lima et al. 2016: Fig. 4B, C, 5B, D). The east-west pattern in the distribution is most prominent in $U$. pictorum, less so

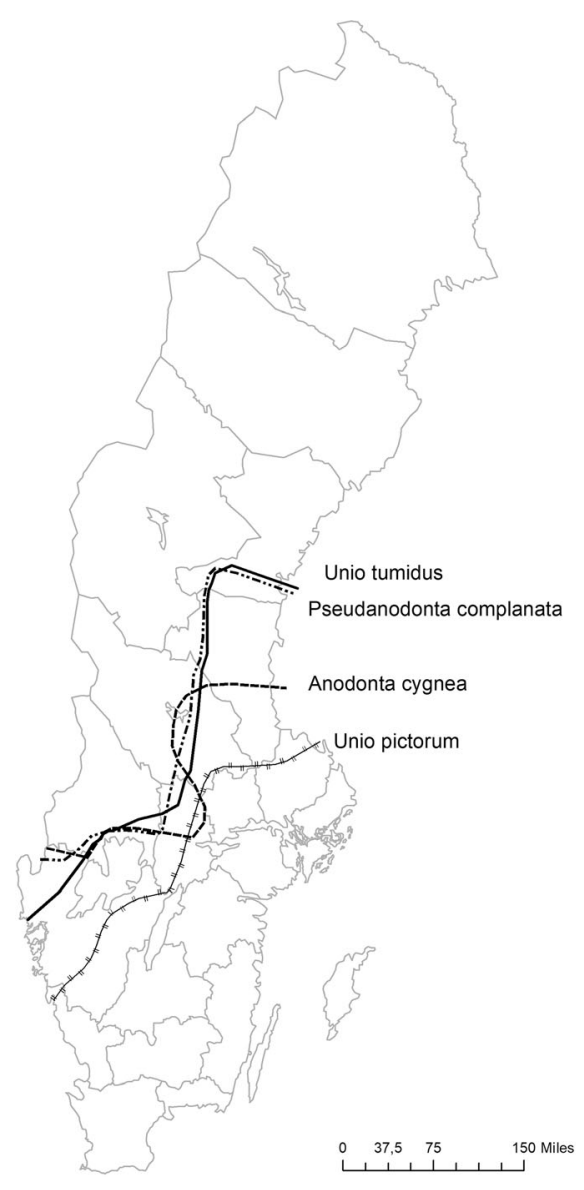

$N$

Fig. 11 Northern limits of U. tumidus, P. complanata, A. cygena and $U$. pictorum in Sweden. Note the gathering of the limits in the so called limes norrlandicus-zone

in the other species, which however are somewhat more common in the east (cf. distribution maps Figs. 3, 4, 7, 8 and the compilation of northern limits in Fig. 11). Also compare the marked difference in distribution to the less demanding and throughout the country common and widespread A. anatina (Fig. 6) and the marked eastern-continental $U$. crassus (Fig. 5). For U. pictorum, U. tumidus and U. crassus the Swedish localities also form the species northwestern distribution limit. For A. cygnea and $P$. complanata, this is partly the case, but they also have a few occurrences in the south-easternmost corner of Norway (Økland \& Andersen, 1985; Larsen et al., 1999; Sandaas et al., 1999), which bio-geographically is situated south of the limes. A. anatina occurs in the same area of Norway as the species mentioned above (Larsen et al., 1999) but also follows the south coast of 
Norway to the province of Aust-Agder (Dolmen \& Klevlein, 1999).

The diversity of unionoid mussel species is markedly higher in eastern Sweden, than in western, although only five large river systems, all running eastwards and discharging in the Baltic Sea (rivers Helge å, Emån, Motala ström and Kilaån, see Fig. 1.) contain, or have contained, all seven native species. The most marked differences are the absence of $U$. crassus in the west and the fact that $U$. pictorum is very rare in this area. None of the river systems of the five largest westward draining Swedish rivers (Lagan, Nissan, Ätran, Viskan and Göta Älv, see Fig. 1.) have more than six species. A part of the explanation is probably that large parts of the Western Swedish water systems are predominantly oligotrophic, and hence less suitable for less tolerant species (compared to $A$. anatina) like A. cygnea, $P$. complanata and $U$. pictorum. West Sweden also has a pronounced Atlantic climate with high precipitation mild winters and rather cold summers, contrasting to the continental climate in the East.

\section{Taxonomy}

Possible sub-specific taxonomy (subspecies) in Sweden is not treated in the present paper. In some of the Europaean Unionoida-species, especially U. crassus, $U$. tumidus and $P$. complanata, the opinions on several of their morphological forms vary, and the status of these could not be considered as conclusively solved (cf. e.g., different opinions in Nesemann, 1993a, b; Zettler, 1997, 2000; Falkner et al., 2002; Prié \& Puliandre, 2014; Mioduchowska et al., 2016; Prié, 2017). It should, however, be stressed that if subspecies are recognized within $U$. crassus and $U$. tumidus, the taxon occurring in Sweden has been ascribed to the nominotypical subspecies in both cases (Nesemann, 1993a; Falkner et al., 2001). The Swedish (N. European) Pseudanodonta-form is morphologically P. complanata klettii (Rossmässler, 1835).

\section{Ecology}

The Swedish unionids have a lot in common with their conspecifics in the rest of Europe but there are some interesting differences, especially the utilization of different host fish species.
Host fishes are essential for the dispersal of freshwater mussels (Modesto et al., 2018) and a better understanding of the interaction between the species would help when trying to understand distribution patterns for different mussel species. The host fish diversity is not fully understood for any of the unionoid mussel species in Sweden. Comparisons of host fish diversity between the different European countries is not an easy task, as different countries have used different methods to deal with these questions, and only a few have investigated other species than U. crassus and M. margaritifera (Berri \& Boize, 1985; Blazek \& Gelnar, 2006). Our data compared to the rest of Europe indicate that some fish species are shared over Europe, e.g., P. fluviatilis have been reported as an important host to $U$. pictorum and U. tumidus (Berri \& Boize, 1985; Blazek \& Gelnar, 2006) and for A. anatina in Finland (Jokela et al. 1991). While other fish species, like $R$. rutilus, seem to be more important to $U$. pictorum and $U$. tumidus in Swedish rivers than in rivers in Czech Republic (Blazek \& Gelnar, 2006). Gasterosteus aculeatus (Linnaeus, 1758) has been reported as an important fish hosts to $U$. pictorum and $U$. tumidus in the river Thames in the U.K. (Berri \& Boize, 1985), but there are no indications that this fish species is important to unionids in Sweden. Leuciscus idus (Linnaeus, 1758) is a common fish species in Sweden which has not yet been reported as host fish to any of the unionid species in Sweden, but it is reported as host to Unio species in the river Morava and the river Kyjovka in Czech Republic (Balzek \& Gelnar, 2006). Squalis cephalus (Linnaeus, 1758) is another quite common fish species in Sweden which has been reported as host fish to $U$. crassus and U. pictorum, and it is also a host to Unio species in the Czech Republic (Blazek \& Gelnar, 2006) and to U. crassus in Germany (Taeubert et al., 2012).

The most studied unionid species in Sweden and Europe in terms of host fish diversity is U. crassus. In the Life project UC4LIFE several streams within the distribution area of the species where investigated and the results show that the glochidia can infest several fish species but A. alburnus, C. gobio and P. phoxinus seems to be the most important host fish in Sweden (Lundberg \& Österling, 2016). From Germany we know that $P$. phoxinus, Chondrostoma nasus (Linnaeus, 1758), Scardinius erythrophthalmus (Linnaeus, 1758) and S. cephalus are considered good hosts 
(Taeubert et al., 2012). The Taeubert study (2012) has not listed A. alburnus as a host, and C. gobio is listed as a good-poor host, but in Sweden we consider both species to be good hosts (Lundberg \& Österling, 2016). The information from other studies in Europe about the host fish diversity is very useful as a guide, but it is necessary to have your own local data as it seems that local adaptation is an important factor to consider when it comes to determining host fish spectra (Douda et al., 2017). Even with a well-studied species such as the M. margaritifera we need more investigations, such as time series of glochidia prevalence and infection intensity on host fish, to better understand the dynamic and the ecology in a population. Margaritifera margaritifera is known to be a host fish specialist and glochidia can only metamorphose on $S$. salar and/or S. trutta. We believe that brown trout is the most important host to M. margaritifera in Sweden, which has also been reported from other parts of Europe (Geist et al., 2006). We assume this based on the facts that today $S$. salar only reach a fraction of its natural distribution because of barriers in Swedish river systems, and that $S$. trutta can has different life histories and doesn't necessarily need to migrate to sea (Klemetsen et al., 2003). However, in some Swedish river systems, e.g., Ätran, both $S$. salar and S. trutta are functional hosts, but in different parts of the river system, $S$. salar below the first barrier and $S$. trutta above that barrier (Wengström, unpublished data). This pattern was first reported from Norway with $S$. salar and $S$. trutta living in the same river system, but at different locations and both working as functional hosts to M. margaritifera (Karlsson et al., 2014). There are indications that some of the big river systems in the northern Sweden have the same pattern, but this needs further investigations.

\section{Conservation}

The Swedish conservation work with unionids has so far only involved M. margaritifera and U. crassus, probably because these are the only two unionid species with national actions plans (Henrikson \& Söderberg, 2020; Lundberg et al., 2006), Most likely this will not change, as the other species are considered too common, even though $U$. pictorum and $P$. complanata are on the Swedish red list for threaten species. However, it is likely that both $U$. pictorum and $P$. complanata may be helped from the work that has been done on $U$. crassus, as the species often co-occur in streams. Both $U$. pictorum and $P$. complanata remain on the Swedish red list in the category Near threaten, even though they were close to be omitted in the latest assessment, mainly because they had been found on rather many new locations in Sweden (Artdatabanken, 2020). The data concerning these two species in the Swedish databases are scarce, and we need a lot more information about their ecology, populations trends, population genetics, fish host, before we can assess their status in a more correct way. The lack of information is almost the same for $U$. crassus, no demographic data in the database for any of the populations. A population genetics study has recently been performed, but the results have not been published yet. The lack of knowledge for the more "common" species A. anatina and $U$. tumidus makes it very hard to assess their status, and since there is no national or regional monitoring program their status will remain poorly known and we will continue consider them as "common". The only peer reviewed study from Sweden of the species reports a lack of recruitment in all 33 studied sites in the region of Västra Götaland (Jonsson et al., 2013). The conservation work on M. margaritifera has been going on for more than three decades in Sweden and both conservation areas and several habitat restorations projects have been performed to help the species. There is an estimated number of individuals of 39 million $M$. margaritifera in Sweden (Henrikson \& Söderberg, 2020). Sweden, together with Norway and Russia, are stronghold countries for the species and Sweden has a responsible to maintain it for the future. The lack of recruitment in $50 \%$ of the populations is problematic and difficult to overcome. Up until now Sweden has had no propagation program for the species, but in the revised action plan it is suggested to promote artificial breeding in prioritized streams (Henrikson \& Söderberg, 2020).

The work with distribution and ecology of freshwater mussels in Sweden is an ongoing process. New data gather continuously in regional and national mussel data bases - and large mussel materials are sent in for determination/verification/registration/storage in the collections of Gothenburg Natural History Museum. This is all good but as we have already mentioned in the text above, several of the unionoid species in Sweden are relatively unknown concerning ecology and conservation status. We would like to 
stress some future areas of interest that could benefit the Swedish conservation work with unionids: A genetic mapping of the populations of the species on the national red list (M. margaritifera, $U$. crassus, $U$. pictorum and $P$. complanata); Future studies on the ecology and demography of the species $U$. crassus, $U$. pictorum and $P$. complanata; And last but not least, demographic studies also on the more common species A. anatina, A. cygnea and U. tumidus.

Acknowledgements Open access funding provided by University of Gothenburg. We want to express our thanks to all that have contributed with mussel records and material during the years, especially should be mentioned the Administrative Boards of all 21 Swedish Counties, the Natural History Museums in Gothenburg, Lund, Stockholm and Uppsala, Stefan Lundberg (Vaaka Naturkonsult, Bromma), Lennart Henrikson (Natur och människa, Hyssna), Per Ingvarsson (PI Fly Vatten- och Fiskevård, Laholm), CarlJohan Månsson (The Rural Economy and Agricultural Society, Blekinge-Kalmar-Kronoberg) and Michael Svensson (Osby). We are also grateful to Torsten Nordander and Peter Nielsen (Gothenburg Natural History Museum) for mapping all the compiled mussel-record data, and to Ulf Bjelke (Swedish Species Information Centre, SLU, Uppsala) for information on the national the red listing 2015 and 2020.

Open Access This article is licensed under a Creative Commons Attribution 4.0 International License, which permits use, sharing, adaptation, distribution and reproduction in any medium or format, as long as you give appropriate credit to the original author(s) and the source, provide a link to the Creative Commons licence, and indicate if changes were made. The images or other third party material in this article are included in the article's Creative Commons licence, unless indicated otherwise in a credit line to the material. If material is not included in the article's Creative Commons licence and your intended use is not permitted by statutory regulation or exceeds the permitted use, you will need to obtain permission directly from the copyright holder. To view a copy of this licence, visit http://creativecommons.org/licenses/by/4.0/.

\section{References}

Ájtte, Svenskt Fjäll- och Samemuseum och Kungliga Vetenskapsakademien (eds), 1995. Flodpärlmusslan ur tvärvetenskaplig belysning. Rapport från seminarium hållet vid Ájtte, Svenskt Fjäll- och Samemuseum 1992. Duoddaris 7.

Aldridge, D. C., 1999. The morphology, growth and reproduction of unionidae (Bivalvia) in a Fenland Waterway. Journal of molluscan studies 65: 47-60.

Aldridge, D., 2011. Pseudanodonta complanata. The IUCN Red List of Threatened Species 2011: e.T18446A8279656. Downloaded on 21 June 2020.
Aldridge, D., Z. Fehér,. \& T. von Proschwitz, 2011. Unio crassus. The IUCN Red List of Threatened Species 2011: e.T22736A9381770. Downloaded on 21 June 2020.

Andersson, M., 2020. Test of host fish quality for the duck mussel (Anodonta anatina L.) - a mortality and survival test on glochidia. Bachelor thesis, University of Gothenburg.

ArtDatabanken (eds), 2015a. Rödlistade arter i Sverige 2015. [Swedish species information centre: Red-listed species in Sweden 2015]. ArtDatabanken SLU, Uppsala. 209 pp.

ArtDatabanken, 2015b. Manual och riktlinjer för rödlistning i Sverige 2015 [Swedish species information centre: Manual and guidelines for red-listing in Sweden 2015] www.slu.se/ artdatabanken

ArtDatabanken (eds), 2020. Rödlistade arter i Sverige 2020. [Swedish species information centre: Red-listed species in Sweden 2020]. ArtDatabanken SLU, Uppsala.

Awebro, K., 1995. Pärlfisket som statligt privilegium under åren 1691-1723 [Flodpärlmusslan i tvärvetenskaplig belysning. Rapport från seminarium hållet vid Ájtte, Svenskt Fjälloch Samemuseum 1992]. Duoddaris 7: 93-133.

Başçınar, N. S. \& E. Düzgüneş, 2009. A Preliminary study on reproduction and larval development of Swan Mussel [Anodonta cygnea (Linnaeus, 1758)] (Bivalvia: Unionidae), in Lake Çıldır (Kars, Turkey). Turkish Journal of Fisheries and Aquatic Sciences 9: 23-27.

Bauer, G., 1987. Reproductive strategy of the freshwater Pearl Mussel Margaritifera margaritifera. Journal of Animal Ecology 56: 691-704.

Bergengren, J., \& S. Lundberg, 2009. Nationell Musselövervakning. Förslag till val av nationella musselvatten. Avrapportering enligt avtal 216 0832. Länsstyrelsen i Jönköpings län, PM 2009: 1. 51 pp.

Bergengren, J., T. von Proschwitz, \& S. Lundberg, 2002. Stormusselprojektet 2001. Utveckling av metodik och undersökningstyp. Beskrivning av habitatval. Förekomst i fem län i södra Sverige. Länsstyrelsen i Jönköpings län, Meddelande 2002: 19A. 129 pp. Jönköping. [English summary, pp. 15-18: The large freshwater mussel project in Sweden 2001 - Development of monitoring methods, description of habitat selection and occurrence in five provinces in S. Sweden.]

Bergengren, J., T. von Proschwitz, \& S. Lundberg, 2002. Stormusselprojektet 2001. Lokalbeskrivningar. Länsstyrelsen i Jönköpings län, Meddelande 2002: 19B. 97 pp. Jönköping.

Bergengren, J., T. von Proschwitz, S. Lundberg, H. Söderberg, \& O. Norrgrann, 2010. Undersökningstyp: Stormusslor. Naturvårdsverket, Version 2010-03-30.

Bergengren, J., J.-E. Svensson, T. von Proschwitz, \& S. Lundberg, 2015. A recent Dreissena invasion in an old canal system in northern Europe. In Mehler, K., L. E. Burlakova, A. Y. Karatayev \& S. Dickinson, (eds), 2nd Internqational Meeting on Biology and Conservation of Freshwater Bivalves, Buffalo Oct. 4-8, 2015. Book of Abstracts: 46.

Berrie, A. D., \& B. J. Boize, 1985. The fish hosts of Unio glochidia in the River Thames. Internationale Vereinigung für Theoretische und Angewandte Limnologie: Verhandlungen, 1922-2010 22: 2712-2716.

Björk, S., 1962. Investigations on Margaritifera margaritifera and Unio crassus. Limnologic studies in rivers in South Sweden. Acta Limnologica 4: 5-109. 
Blažek, R. \& M. Gelnar, 2006. Temporal and spatial distribution of glochidial larval stages of European unionid mussels (Mollusca: Unionidae) on host fishes. Folia Parasitologica 53: 98-106.

Bogan, A. E., 1993. Freshwater bivalve extinctions (Mollusca: Unionoida): a search for causes. American zoology 33: 599-609.

Bogan, A. E., 2008. Global diversity of freshwater mussels (Mollusca, Bivalvia) in freshwater. Hydrobiologia 595: 139-147.

Dolmen, D. \& E. Kleiven, 1999. Funn av andemusling Anodonta anatina i Aust-Agder. Fauna (Oslo) 52: 69-74.

Douda, K., H.-Z. Liu, D. Yu, R. Rouchet, F. Liu, Q.-Y. Tang, C. Methling, C. Smith \& M. Reichard, 2017. The role of local adaptation in shaping fish-mussel coevolution. Freshwater Biology 62: 1858-1868.

Dudgeon, D., A. H. Arthington, M. O. Gessner, Z.-I. Kawabata, D. J. Knowler, C. Lèvêque, R. J. Naiman, A.-H. PrieurRichard, D. Soto, M. L. J. Stiassny \& C. A. Sullivan, 2006. Freshwater biodiversity: importance, threats, status and conservation challenges. Biological Reviews 81: 163-182.

Eriksson, M. O. G., L. Henrikson, \& H. Söderberg (eds), 1998. Flodpärlmusslan i Sverige - statu, trender och hotbild. [The Freshwater Pearl Mussel Margaritifera margaritifera in Sweden: status, trends and theats]. Naturvårdsverket. Rapport 4887. Stockholm.

Falkner, G., R. A. Bank \& T. von Proschwitz, 2001. Check-list of the non-marine Molluscan Species-group taxa of the States of Northern, Atlantic and Central Europe (CLECOM I). Heldia 4(1/2): 1-76.

Falkner, G., T. E. J. Ripken, \& M. Falkner, 2002. Mollusques continentaux de France, Liste de référence annotée et bibliographie. Patrimoines Naturels 52. (Museum National d'Histoire Naturelle). 350 pp.

Faust, C., D. Stallknecht, D. Swayne \& J. Brown, 2009. Filterfeeding bivalves can remove avian influenza viruses from water and reduce infectivity. Proceedings of the Royal Society B-Biological Sciences 276: 3727-3735.

Florin, A. B., K. Mo, F. Svensson, E. Schagerström, L. Kautsky \& L. Bergström, 2013. First record of Conrad's false mussel, Mytilopsis leucophaeata (Conrad, 1831) in the southern Bothnian Sea, Sweden, near a nuclear power plant. Bioinvasion Records 2: 303-309.

Fries, M., 1948. Limes norrlandicus-studier, en växtgeografisk gränsfråga historiskt belyst och exemplifierad. Svensk Botanisk Tidskrift 43: 51-69.

Froufe, E., M. Lopes-Lima, N. Riccardi, S. Zaccara, I. Vanetti, J. Lajtner, A. Texiera, S. Varandas, V. Prié, A. Zieritz, R. Sousa \& A. E. Bogan, 2017. Lifting the curtain on the freshwater mussel diversity of the Italian Peninsula and Croatian Adriatic coast. Biodiversity and Conservation 26(14): 3255-3274.

Geist, J., M. Porkka \& R. Kuehn, 2006. The status of host fish populations and fish species richness in European freshwater pearl mussel (Margaritifera margaritifera) streams. Aquatic Conservation: Marine and Freshwater Ecosystems 16: 251-266.

Graf, D. L. \& K. S. Cummings, 2007. Review of the systematics and global diversity of freshwater mussel species (Bivalvia: Unionoida). Journal of Molluscan Studies 73: 291-314.
Grundelius, E., 1987. Flodpärlmusslans tillbakagång i Dalarna. Information från Sötvattenslaboratoriet, Drottningholm 4 [1987].

Haag, W. R., 2019. Reassessing enigmatic mussel declines in the United states. Freshwater Mollusk Biology and Conservation 22: 43-60.

Hastie, L. C. \& M. R. Young, 2003. Timing of spawning and glochidial release in Scottish freshwater pearl mussel (Margaritifera margaritifera) populations. Freshwater Biology 48: 2107-2117.

Henrikson, L., \& S. Alexanderson, 2012. The EU LIFE project "The freshwater pearl mussel and its habitats in Sweden" In: Henrikson, L., B. Arvidsson, \& M. (eds) Aquatic Conservation with Focus on Margaritifera margaritifera. Proceedings of the International Conference in Sundsvall, Sweden, 12-14 August, 2009. Karlstad University Studies 2012: 40: 5-10.

Henrikson, L. \& H. Söderberg, 2020. Åtgärdsprogram för flodpärlmussla. Havs- och Vattenmyndigheten. Rapport 2020: 19.

Henrikson, L., H. Schreiber \& L. Tranvik, 2005. Åtgärdsprogram för bevarande av flodpärlmussla. Naturvårdsverket, Rapport: 5429.

Hinzmann, M., M. Lopes-Lima, A. Teixeira, S. Varandas, R. Sousa, A. Lopes, E. Froufe \& J. Machado, 2013. Reproductive cycle and strategy of Anodonta anatina (L., 1758): Notes on hermaphroditism. Journal of Experimental Zoology 319: 378-390.

Hård af Segerstad, F., 1935. Pflanzengeographische Studien im nordwestlichen Teil der Eichenregion Schwedens, I und II. Arkiv för Botanik 27A: 1-405.

Ismail, N. S., H. Dodd, L. M. Sassoubre, A. J. Horne, A. B. Boehm \& R. G. Luthy, 2015. Improvement of urban lake water quality by removal of Escherichia coli through the action of the bivalve Anodonta californiensis. Environmental Science \& Technology 49: 1664-1672.

Izumi, T., K. Yagiti, S. Izumiyami, T. Endo \& Y. Ituh, 2012. Depletion of Cryptosporidium parvaum oocysts from contaminated sewage using freshwater benthic pearl clams (Hyriopsis schlegeli). Applied and Environmental Microbiology 78: 7420-7428.

Jokela, J., E. T. Valtonen \& M. Lappalainen, 1991. Development of glochidia of Anodonta piscinalis and their infection of fish in a small lake in northern Finland. Archiv für Hydrobiologie 120: 345-356.

Jonsson, A. \& A. Bertilsson, 2016. Ökad biologisk mångfald och renare vatten med livskraftiga stormusselbestånd $\mathrm{i}$ Göta Älvs vattensystem. Institutionen för Biovetenskap Högskolan i Skövde.

Jonsson, A., A. Bertilsson \& M. Rydgård, 2013. Spatial distribution and age structure of the freshwater unionid mussels Anodonta anatina and Unio tumidus: implications for environmental monitoring. Hydrobiologia 711: 61-70.

Karlsson, S., B. M. Larsen \& K. Hindar, 2014. Host-dependent genetic variation in freshwater pearl mussel (Margaritifera margaritifera L.). Hydrobiologia 735: 179-190.

Kat, P. W., 1984. Parasitism and the Unionacea (Bivalvia). Biological Reviews 59: 189-207.

Killeen, I. \& D. Aldridge, 2011. Anodonta cygnea. The IUCN Red List of Threatened Species 2011: e.T156066A4907255. Downloaded on 21 June 2020. 
Killeen, I. \& L. Vavrova, 2011. Anodonta anatina. The IUCN Red List of Threatened Species 2011: e.T155667A4818080. Downloaded on 21 June 2020.

Klemetsen, A., P.-A. Amundsen, J. B. Dempson, B. Jonsson, N. Jonsson, M. F. O'Connell \& E. Mortensen, 2003. Atlantic salmon Salmo salar L., brown trout Salmo trutta L. and Arctic charr Salvelinus alpinus (L.): a review of aspects of their life histories. Ecology of Freshwater Fish 12: 1-59.

Kuiper, J. G. J., K.-A. Økland, J. Knudsen, L. Koli, T. von Proschwitz \& I. Valovirta, 1989. Geographical distribution of the small mussels (Sphaeriidae) in North Europe (Denmark, Faroes, Finland, Iceland, Norway and Sweden). Annales Zoologici Fennici 26: 73-101.

Källersjö, M., T. von Proschwitz, S. Lundberg, P. Eldenäs \& C. Erséus, 2005. Evaluation of ITS rDNA as a complement to mitochondrial gene sequences for phylogenetic studies in freshwater mussels: an example using Unionidae from north-western Europe. Zoologica Scripta 34: 415-424.

Larsen, B. M., R. Hartvigsen, K. A. Økland \& J. Økland, 1999. Utbredelsen av andemusling Anodonta anatina, svanemusling Anodonta cygnea og flat dammusling Pseudanodonta complanata i Norge. Fauna (Oslo) 52: 58-68.

Larsson, M., 2015. Interaction between fish and freshwater mussels - determination of functional hosts for the thickshelled river mussel, Unio crassus. Master thesis, University of Gothenburg.

Lindström, T. 2007. Habitatpreferenser för tjockskalig målarmussla (Unio crassus) - och andra stora sötvattensmusslor i Kapellån, Östergötland. Master thesis, Linköpings Universitet. (LiU-Biol-Ex-607).

Lopes-Lima, M. 2014a. Anodonta cygnea. The IUCN Red List of Threatened Species 2014. http://dx.doi.org/10.2305/ IUCN.UK.2014-.RLTS.T156066A21400900.en.

Lopes-Lima, M. 2014b. Anodonta anatina. The IUCN Red List of Threatened Species 2014. http://dx.doi.org/10.2305/ IUCN.UK.2014-1.RLTS.T155667A21400363.en.

Lopes-Lima, M., U. Kebapçı \& D. Van Damme, 2014c. Unio crassus. The IUCN Red List of Threatened Species 2014: e.T22736A42465628. https://dx.doi.org/10.2305/IUCN. UK.2014-1.RLTS.T22736A42465628.en.

Lopes-Lima, M., R. Sousa, J. Geist, D. C. Aldridge, R. Araujo, J. Bergengren, Y. Bespalaya, E. Bódis, L. Burlakova, D. Van Damme, K. Douda, E. Froufe, D. Georgiev, C. Clumpinger, A. Karatayev, Ü. Kebapci, I. Killeen, J. Lajtner, B. M. Larsen, R. Lauceri, A. Legakis, S. Lois, S. Lundberg, E. Moorkens, G. Motte, K.-O. Nagel, P. Ondina, A. Outeiro, M. Paunovic, V. Prié, T. von Proschwitz, N. Riccardi, M. Rudzīte, M. Rudzītis, C. Scheder, M. Seddon, H. Şereflişan, V. Simić, S. Sokolova, K. Stoeckl, J. Taskinen, A. Teixeira, F. Thielen, T. Trichkova, S. Varandas, H. Vicentini, K. Zajac, T. Zajac \& S. Zogaris, 2016. Conservation status of freshwater mussels in Europe: state of the art and future challenges. Biological Reviews 92: 572-607.

Lundberg, M. 2012. Habitatpreferenser hos tjockskalig målarmussla (Unio crassus) med avseende på vattendjup och beskuggning. Master thesis, Technical University of Linköping, Sweden [LiTH-IFM-G-Ex-12/2665-SE)].

Lundberg, S., \& M. Österling (eds), 2016. Return of the Thickshelled River Mussel. - restoring floodplains, habitats and connectivity by using mussels and brains. Handbook, UC4LIFE project, Skåne County Administrative Board.
Lundberg, S. \& T. von Proschwitz, 2004. Tjockskalig målarmussla i Södermanlands län. Förekomst, biologi/ekologi, status och skyddsvärde samt förslag till åtgärder för artens bevarande. [English summary: The thick-shelled river mussel (Unio crassus Philipsson, 1788) in the Province of Södermanlands län, E. Sweden]. Länsstyrelsen i Södermanlands län. Rapport 2004: 8. 49 pp.

Lundberg, S., \& T. von Proschwitz, 2007. Mälarens stormusselfauna. Lokalbeskrivningar. - PM från Naturhistoriska riksmuseet 2007: 3. Naturhistoriska riksmuseets småskriftserie. $183 \mathrm{pp}$. Stockholm.

Lundberg, S., J. Bergengren, \& T. von Proschwitz, 2006. Åtgärdsprogram för bevarande av tjockskalig målarmussla (Unio crassus). [Action plan for the conservation of the thick-shelled river mussel, Unio crassus]. Naturvårdsverket. Rapport 5658.

Lydeard, C., R. H. Cowie, W. F. Ponder, A. E. Bogan, P. Bouchet, S. A. Clark, K. S. Cummings, T. J. Frest, O. Gargominy, D. G. Herbert, R. Hershler, K. E. Perez, B. Roth, M. Seddon, E. E. Strong \& F. G. Thompson, 2004. The global decline of nonmarine mollusks. BioScience 54: 321-330.

Mioduchowska, M., A. Kaczmarczyk, K. Zając, T. Zając \& J. Sell, 2016. Gender-associated mitochondrial DNA heteroplasmy in somatic tissues of the endangered freshwater mussel Unio crassus (Bivalvia: Unionidae): implications for sex identification and phylogeographical studies. Journal of Experimental Zoology A Ecological and Inegrative Physiology. 325(9): 610-625.

Modesto, V., M. Ilarri, A. T. Souza, M. Lopes-Lima, K. Douda, M. Clavero \& R. Sousa, 2018. Fish and mussels: importance of fish for freshwater mussel conservation. Fish and Fiskeriers 19: 244-259.

Moorkens, E. 2011. Margaritifera margaritifera. The IUCN red list of threatened species 2011: e.T12799A3382660. Downloaded on 23 June 2020.

Moorkens, E., J. Cordeiro, M. B. Seddon, T. von Proschwitz, \& D. Woolnough, 2017. Margaritifera margaritifera (errata version published in 2018). The IUCN Red List of Threatened Species 2017. http://dx.doi.org/10.2305/IUCN. UK.2017-3.RLTS.T12799A508865.en.

Näslund, J., N. Hellström, \& P. Hellström, 2019. eDNA-inventering av fisk, groddjur och musslor i Skellefteälvens avrinningsområde. AquaBiota Report 2009:16. 22 pp.

Nesemann, H., 1993a. Paläogeographische Indikatorfunktion und Vorkommen der Gemeinen Flussmuschel Unio crassus Philipsson, 1788, in Ostösterreich und Nordwestungarn. Club Conchylia Informationen 25 (2): 167-178.

Nesemann, H., 1993b. Zoogeographie und Taxonomie der Muschel-Gattungen Unio Philipsson 1788, Pseudanodonta Bourguignant 1877 und Pseudunio Haas 1910 im oberen und mittleren Donausystem (Bivalvia: Unionidae, Margaritiferidae). Nachrichtsblatt der Ersten Vorarlberger Malakologische Gesellschaft 1: 20-40.

Økland, J. \& A. Andersen, 1985. De første funn av Pseudanodonta complanata i Norge og litt om andre store muslinger i ferskvann. Fauna (Oslo) 38: 95-100.

Olofsson, P., 2017. Regional Monitoring of Freshwater Pearl Mussel Margaritifera margaritifera in the County of Norrbotten, Sweden. Biology Bulletin 44(1): 74-80. 
Österling, M. E., L. A. Greenberg \& B. L. Arvidsson, 2008. Relationship of biotic and abiotic factors to recruitment patterns in Margaritifera margaritifera. Biological conservation 141: 1365-1370.

Österling, M. E. \& N. Wengström, 2015. Test of the host fish species of a unionoid mussel: a comparison between natural and artificial encystment. Limnologica 50: 80-83.

Pekkarinen, M., 1993. Reproduction and condition of unionid mussels in the Vantaa River, South Finland. Archiv für Hydrobiologie 127: 357-375.

Prié, V., 2017. Naïades et autres bivalves d'eau douce de France. Biotope, Mèze, Museum national d'Histoire naturelle, Paris (collectionInventaires \& biodiversitet. 336 pp.

Prié, V. \& N. Puilandre, 2014. Molecular phylogeny, taxonomy, and distribution of French Unio species (Bivalvia, Unionidae). Hydrobiologia 735(1): 95-110.

Sandaas, K., J. Enerud \& J. I. Larsen, 1999. Svanemusling Anodonta cygnea funnet i Norge. Fauna (Oslo) 52: 75-81.

Schneider, L. D., 2017. Conservation ecology of the thickshelled river mussel - the importance of parasitic-host interactions. PhD Thesis, Department of Environmental and Life Sciences, Faculty of Health, Science and Technology, Karlstad University. Karlstad University Studies $2017 / 7$.

Schneider, L. D., A. P. Nilsson, J. Höjesjö \& M. E. Österling, 2017. Local adaptation studies and conservation: Parasitehost interactions between the endangered freshwater mussel Unio crassus and its host fish. Aquatic Conservation: Marine and Freshwater Ecosystems 27: 1261-1269.

Schneider, L. D., A. P. Nilsson \& M. E. Österling, 2018. Evaluating temperature- and host-dependent reproduction in the parasitic freshwater mussel Unio crassus. Hydrobiologia 810: 283-293.

Schreiber, H., L. Tranvik, \& L. Henrikson, L., 2005. Åtgärdsprogram för bevarande av flodpärlmussla. [Action plan for the conservation of the freshwater pearl mussel, Margaritifera margaritifera]. Naturvårdsverket Rapport 5429. 41 pp. Stockholm.

Söderberg, H., A. Karlberg \& O. Norrgrann, 2008. Status, trender och skydd för flodpärlmusslan i Sverige. Länsstyrelsen Västernorrland, avdelningen för Kultur- och Natur, Rapport 2008: 12.

Taeubert, J.-E., A. M. Posada Martinez, B. Gum \& J. Geist, 2012. The relationship between endangered thick-shelled river mussel (Unio crassus) and its host fishes. Biological Conservation 155: 94-103.

Van Damme, D. 2011. Pseudanodonta complanata. The IUCN Red List of Threatened Species 2011. http://dx.doi.org/10. 2305/IUCN.UK.2011-2.RLTS.T18446A8279278.en.

Vaughn, C., 2018. Ecosystem services provided by freshwater mussels. Hydrobiologia 810: 15-27.

Vavrova, L. 2011. Unio tumidus. The IUCN Red List of Threatened Species 2011: e.T156111A4899186. Downloaded on 21 June 2020.

von Proschwitz, T., 1998. Zoogeography of the small freshwater mussels (Sphaeriidae) on the Scandinavian peninsula. In Bieler, R., P. M. Mikkelsen (eds), Abstracts of the World Congress of Malacology, Washington DC, 25-30 July 1998: 269.

von Proschwitz, T., 2006. Karteringen av limniska stormusslor i Sverige och Norden samt arbetet med en svensk stormusselbibliografi. In: Arvidsson, B. \& H. Söderberg (eds) Flodpärlmussla - vad behöver vi göra för att rädda arten? En workshop på Karlstads universitet. Karlstad University Studies 2006/15: 9-18.

von Proschwitz, T., 2008. The Chinese gigant mussel - Sinanodonta woodiana (Lea, 1834) (Bivalvia Unionidae) - an unwelcome addition to the Swedish fauna. Basteria 72 : 307-311.

von Proschwitz, T., 2012. The freshwater pearl mussel - Margaritifera margaritifera (Linnaeus) - in Sweden during five centuries (1539-2009) - an outlook from the work on a Swedish bibliography on the large freshwater mussels. In: Henrikson, L., B. Arvidsson \& M. Österling (eds), Aquatic Conservation with Focus on Margaritifera margaritifera. Proceedings of the International Conference in Sundsvall, Sweden, 12-14 August, 2009. Karlstad University Studies 2012/40: 21-40.

von Proschwitz, T., 2018. Two invasive brackish water mussel species in Sweden: Rangia cuneata (G. B. Sowerby I) and Mytilopsis leucophaeata (Conrad). Journal of Conchology 43: 111-113.

von Proschwitz, T. \& J. Bergengren, 2012. Det gäller att ha koll på artkunskapen - Hur en pärlfiskedom på 1600-talet ledde till upptäckten av en rik förekomst av den hotade tjockskaliga målarmusslan 340 år senare! [English summary, p. 34: You got to know your species.... How a sentence for illegal pearl-fishery 1670 lead to the detection of a rich occurrence of the threatened thick-shelled river mussel 340 years later!]. Fauna och Flora 107: 28-35.

von Proschwitz, T., S. Lundberg, \& J. Bergengren, 2006. Guide till Sveriges stormusslor. [12 Information leaflets (23 pp.) in folder]. Naturvårdsverket/Naturhistoriska Riksmuseet/ Göteborgs Naturhistoriska Museum.

von Proschwitz, T., S. Lundberg, \& J. Bergengren, 2017. Guide till Sveriges stormusslor. [16 Information leaflets (29 pp.) in folder]. Länsstyrelsen i Jönköpings län/Göteborgs Naturhistoriska Museum/Havs och Vatten Myndigheten. [2nd revised and extended edition].

Waller, D. L. \& G. W. Cope, 2019. The status of mussel health assessment and a path forward. Freshwater Mollusk Biology and Conservation 22: 26-42.

Wengström, N., 2009. Samspelet mellan fiskar och stormusslor Vilka värdfiskar utnyttjas av den tjockskaliga målarmusslan Unio crassus. Master Thesis, University of Gothenburg.

Wengström, N., H. Söderberg, J. Höjesjö \& A. Alfjorden, 2019. Mass mortality events in freshwater Pearl Mussel (Margaritifera margaritifera) populations in Sweden: an overview and indication of possible causes. Freshwater Mollusk Biology and Conservation 22: 61-69.

Wengström, N., A. Gudmundson, J. Andersson, J. Bark, \& T. Helsén, 2020. Flodpärlmusslans status i Västra Götalands län. Inventering av 12 musselvattendrag 2019. Länsstyrelsen i Västra Götalands län Rapport 2020:04.

Willing, M. J., 2015. Two invasive bivalves, Rangia cuneata (GB Sowerby I, 1832) and Mytilopsis leucophaeata (Conrad, 1831) living in freshwater in Lincolnshire, Eastern England. Journal of Conchology 42(2): 189-192.

WWF (eds), 2009. The freshwater pearl mussel and its habitats in Sweden - a LIFE project 2004-2009. Leymen's report, WWF, Solna, Sweden. 20 pp. 
Zettler, M. L., 1997. Morphometrische Untersuchungen an Unio crassus Philipsson 1788 aus dem nordeuropäischen Vereisungsgebiet (Bivalvia: Unionidae). Malakologische Abhandlungen (Dresden) 18(3): 213-232.

Zettler, M. L., 2000. Weitere Bemerkungen zur Morphologie von Unio crassus Philipsson 1788 aus dem nordeuropäischen Verbreitungsgebiet (Bivalvia: Unionidae). Malakologische Abhandlungen 20(1): 73-78.

Zieritz, A., B. Gum, R. Kuehn \& J. Geist, 2012. Identifying freshwater mussels (Unionoida) and parasitic glochidia larvae from host fish gills: a molecular key to the North and Central European species. Ecology and Evolution 2: 740-750.
Zieritz, A., A. E. Bogan, E. Froufe, O. Klishko, T. Kondo, U. Kovitvadhi, S. Kovitvadhi, J. H. Lee, M. Lopes-Lima, J. M. Pfeiffer, R. Sousa, T. Van Do, I.Vikhrev \& D. T. Zanatta, 2018. Diversity, biogeography and conservation of freshwater mussels (Bivalvia: Unionida) in East and Southeast Asia. Hydrobiologia 810: 29-44.

Publisher's Note Springer Nature remains neutral with regard to jurisdictional claims in published maps and institutional affiliations. 